\title{
Matching worker skills to job tasks in the Netherlands: sorting into cities for better careers
}

Suzanne Kok ${ }^{1,2}$

\author{
Correspondence: s.j.kok@rug.n \\ 1 University of Groningen, \\ Groningen, Netherlands \\ ${ }^{2}$ CPB Netherlands Bureau for \\ Economic Policy Analysis, The \\ Hague, Netherlands
}

\begin{abstract}
Matches between workers and jobs are better in thick labour markets than in thin ones. This paper measures match quality by the gap between worker skills and their job tasks in the Netherlands. The smaller the gap, the better the match between skills and tasks. The measured gaps are 14 percent of a standard deviation smaller in cities than in the Dutch countryside. The location of work explains the observed higher quality of matches, while the location of residence does not. Robustness analyses show that these results are not explained by more efficient learning in cities or the spatial distribution of industrial and service occupations. Higher matching quality is associated with higher wages and explains part of the urban wage premia.
\end{abstract}

JEL Codes: J24; J23; R12; R23

Keywords: Matching; Skills; Tasks; Cities

\section{Introduction}

The matching of workers to jobs is better in thick labour markets than in thin ones. The benefits of thick labour markets first gained attention with the work of Alfred Marshall (1920). A thick labour market is associated with both a better chance of a job match and better match quality. An extensive literature has studied whether the chances of a job match rise with market size. The empirical evidence is, however, ambiguous (for a survey, see Petrongolo and Pissarides (2001)). Both workers and employers likely raise their match standards when they have more choice. This results in constant returns to scale for the matching chance and increasing returns to scale in match quality (Petrongolo and Pissarides 2006). Empirical work on the quality of matches is scarce, mainly because it is hard to define quality (Rosenthal and Strange 2004). In a first attempt, Petrongolo and Pissarides (2006) proxy the quality of the match using wages.

The present paper compares the quality of matches between thick city labour markets and thin ones in the Netherlands. The extent to which the skills of workers suit their job tasks is used to define job match quality. Heterogeneity in both worker skills and job tasks is considered in match quality, in addition to commonly used education level and occupation codes. This paper thus extends the work of Petrongolo and Pissarides (2006) by applying a more detailed measure of match quality. We find that the quality of the

(C2014 Kok; licensee Springer. This is an Open Access article distributed under the terms of the Creative Commons Attribution License (http://creativecommons.org/licenses/by/2.0), which permits unrestricted use, distribution, and reproduction in any medium, provided the original work is properly cited. 
match is indeed significantly better in Dutch cities than in the Dutch countryside. The better career prospects induce better workers and more complex jobs to gravitate to cities.

To assign skills to tasks across labour markets, we propose a model in the spirit of Burdett and Coles (1997) and Gautier et al. (2010). The model considers heterogeneous workers searching for a job and employers holding heterogeneous jobs for which they are seeking workers. Workers seek the most complex and subsequently best-paying jobs they can obtain. Employers seek the most skilled workers willing to accept the job, since more skilled workers are more productive. The 'distance' between worker skills and job complexity determines the quality of the match: the smaller the distance, the better the match. Workers and jobs are divided into quality segments. Hence, the maximum difference between worker skills and job complexity is the difference between the least (most) skilled worker in a segment and the most (least) complex job in the same segment. Workers and employers choose a location to work/operate in before they start their search. The economy has two locations: a scarcely populated countryside and a densely populated city. The density of the city results in a better match quality but also higher rents. Because of these better matching qualities, the expected utility of the matches depends more on the quality of workers and jobs in cities than the more 'random' assignments in the countryside. Relatively more skilled workers and more complex jobs sort into the city, since they have higher opportunity costs. The advantages of better matches soon exceed the disadvantage of higher rents in the city.

Empirically, we employ the Longitudinal Internet Studies for the Social Sciences (LISS) panel of 3,000 Dutch individuals. The panel contains information about the suitability of skills for a person's job and additional information about personalities, job tasks, and the usual demographic, occupational, and educational variables. In contrast with the commonly used Occupational Information Network (ONET) and Dictionary of Occupational Titles (DOT) datasets of job tasks, the LISS panel contains person-level instead of occupation-level information. As indicated by Autor and Handel (forthcoming), the within occupation differences in task packages are substantial, which makes our dataset relevant. Each respondent indicates the suitability of his or her job skills, the importance of 33 broad job tasks within the job, and statements about personality. The indicated suitability is used as an estimation of the quality of the match between the worker's skills and job tasks. ${ }^{1}$ Information about preferences, as in preferring complex problems to simple problems, proxies for the investment a person has made in developing skills, given his or her education. We assume, for instance, that workers who prefer complex over simple problems invest more in their cognitive skills than workers with the same education who prefer simple problems. The importance of certain job tasks, given the occupation, defines the job's complexity. In line with the work of Heckman et al. (2006), Borghans et al. (2006), and Bacolod et al. (2009), we can decompose skills and tasks into cognitive and social worker skills and job tasks. We define the quality of a match as the inverse gap between cognitive (social) skills and cognitive (social) job tasks.

Our results can be summarised as follows. The skills of workers in Dutch cities suit their job tasks better than the average suitability in the Dutch countryside. In addition, spatial variation in match quality exists within occupations. Given the occupation, the match of skills to tasks is 14 percent of a standard deviation better in cities than in the Dutch countryside. The spatial patterns for industrial occupations resemble that of service occupations but are less extensive. Regions outside the Randstad area show stronger spatial 
variation than those within the Randstad area, which operate more as a single regional labour market. As expected, more skilled workers sort into cities. Additional analyses suggest that work location choice for more skilled workers is mainly based on job opportunities. Learning mechanisms raise the skills of workers in cities only slightly more than in the countryside, but this does not explain the variation in match quality. Lastly, we show that better match quality is associated with higher wages. Thick labour markets in the Netherlands have advantages in terms of more productive matches.

Labour demand and supply matching is one of the three microfoundations of urban agglomeration economies, suggested by Duranton and Puga (2004), and a commonly cited source for agglomeration externalities. The frameworks of Helsley and Strange (1990), Kim (1990), and Kim (1991) generate externalities whereby the expected match quality increases with the size of the local market. The model of Duranton and Puga (2004) extends this mechanism by showing that the stronger competition for labour in cities results in additional agglomeration economies. Wheeler (2001) suggests that lower search costs in cities result in better matches, greater output per worker, more wage inequality, and higher expected returns to worker skills. Venables (2011) finds that the better match quality derives from the city's signalling function and crowding costs. The empirical evidence for these models is scarce. Petrongolo and Pissarides (2006) find positive scale effects in both post-employment and reservations wages. This study contributes to this work by analysing the spatial variation in the match between worker skills and job tasks. In a different field but using the same underlying mechanism, Costa and Kahn (2001) find that the overrepresentation of power couples in cities can be explained by better dual career possibilities with better chances and better match quality. Gautier et al. (2010) show that more attractive singles sort into cities for better matches. di Giovanni et al. (2012) apply the thick-market effect in the field of international trade and argue that countries with larger populations have more firms and products.

The rest of the paper is organised as follows. Section 2 proposes a matching model to guide empirical analyses about spatial variation in match quality. The strategy of these empirical analyses is presented in Section 3. Section 4 discusses the results of the empirical analyses. Section 5 presents some additional analyses to rule out other mechanisms and calculates some back-of-the-envelope wage returns of match quality. Section 6 offers some concluding remarks.

\section{Model}

We consider a labour market in the spirit of Burdett and Coles (1997) and Gautier et al. (2010). ${ }^{2}$ In the labour market, heterogeneous workers are assigned to heterogeneous jobs. Skill level characterises workers while complexity level characterises jobs. More skilled workers have a comparative advantage in more complex jobs. Skill and complexity level are indexed continuously: the shorter the distance between worker skills and job complexity, the better the quality of the match. Employers holding a vacancy seek the most skilled worker who wants the job, while workers search for the most complex job they can get. Our economy consists of two locations: the city, with a high density of agents, and the countryside, with a low density. ${ }^{3}$ Workers (employers) decide where to work (operate) before they enter the market. Working in the city is more expensive than working in the countryside. However, the thicker labour market of the city increases the possible matches for workers and employers, which tightens matches. 


\subsection{Basic setting}

The model only considers searching workers and job openings. We assume that both workers and employers seek a 'lifetime' deal; hence nobody considers taking a job or filling a vacancy for just a few years. ${ }^{4}$ Once a job or a worker is chosen, there is no turning back. Quitting or firing is ruled out. An agent's choice of location is indexed $l \in[0,1]$, with $0=$ countryside and $1=$ city. The countryside is a scattered location and its population density remains low, even if many work seekers and employers choose to be located there. City life is more expensive; $\Delta c=c_{1}-c_{0}$ defines the additional costs in the city. These additional costs reflect higher private and business rents (which are exogenous in this model) for workers this could also reflect the commuting price of travel from a cheap location to the city for work. ${ }^{5}$

The quality of workers is defined by their skill level $a$. We assume that a worker's skills are given and do not vary across locations. When a worker performs a job in the city, the skills are the same as when the job is performed in the countryside. We relax this assumption in the sensitivity analyses. Employers hold vacancies with complexity $\alpha$. In addition, job complexity is static. Both workers and employers try to optimise their utility: workers search for the most complex and best paid jobs they can obtain. Worker $a$ maximises the nominal wage:

$$
w(a, l)=\alpha-c_{l} .
$$

More complex jobs pay more. All workers earn the same wage for a certain job, regardless of their skills. The variable $c_{l}$ reflects the location costs of location $l$. Employers maximise their revenue and seek the most skilled worker willing to accept the job. The revenue of job $\alpha$ depends on the skills of the worker, $a$, and the costs of the city:

$$
r(\alpha, l)=a-c_{l} .
$$

The revenue of the job increases with worker skills. For the employer, a more skilled worker is more valuable than a less skilled worker who needs additional job training. The amount of training costs required for the job and, in turn, the employer's revenue, decreases with worker skills (Helsley and Strange 1990). For simplicity, we further assume that workers and employers face the same location costs.

\subsection{Search segments}

We now define the segments in which workers and employers search for possible matches. A worker with skills $a$ who is willing to settle for a job with complexity $\alpha^{*}$ is also willing to settle for all jobs with $\alpha>\alpha^{*}$ as wages increase with complexity. Workers and jobs are classified into segments $z$, for example, labelled by educational categories. Each worker searches for a job within his or her segment and each employer seeks a worker within the job's segment. Segments are exogenously given. The segments operate as 'labels' for workers and jobs. A worker with a university degree never accepts a job for a high school graduate and employers with a vacancy for a university graduate never invite a high school graduate to a job interview. ${ }^{6}$ The labour market can be decomposed into a number of consecutive, non-overlapping segments. The first segment contains the workers with the highest skill levels and the jobs with the highest complexity and wages. Workers and employers never match outside their segments of the market. 
Workers maximise their expected nominal wage, given their segment, while choosing a job and do not consider possible promotions or job changes:

$$
w(a, l)=\max \left[E_{l} w\left(\alpha_{z}, l\right)-w\left(\alpha_{z}^{-}\right)-c_{l}\right],
$$

where $\alpha_{z}^{-}$is the least complex job of segment $z$. A worker's wage is always positive, since accepting the worst-paying job is always more beneficial than remaining a job seeker: $w\left(\alpha^{-}\right)>0$.

Similar, employers maximise job revenue, given the segment $z$ of the job. Employers consider a one-time match for a lifetime. Once hired, a worker cannot be fired:

$$
r(\alpha, l)=\max _{l}\left[r\left(a_{z}, l\right)-r\left(a_{z}^{-}\right)\right]-c_{l} .
$$

where $r\left(a_{z}^{-}\right)$is the revenue the least skilled worker of the segment produces. For an employer, letting a worker perform the job is always more beneficial than leaving the job vacant: $r\left(a^{-}\right)>0$. Note that in contrast with the standard model of Pissarides (2000) the value of being unemployed and the value of vacancy is zero. Let $S_{z, l}$ be the mass of job seekers and $V_{z, l}$ the mass of vacancies in segment $z$, location $l$. All job seekers and vacancies are 'new'; the number of seekers and vacancies is related only to the size of the market and not to market clearing. Larger markets have more seekers and vacancies: $S_{z, 1}>S_{z, 0}$ and $V_{z, 1}>V_{z, 0}$. The utility, in terms of wage or revenue, of a segment match is always positive for workers and for employers. Thus, the number of matches $m$ of job seekers to vacancies is

$$
m_{z, l}=\min \left(S_{z, l}, V_{z, l}\right)
$$

Given the number of vacancies and job seekers, the maximum number of matches in the local market is created. ${ }^{7}$ If the number of job seekers in the market $(z, l)$ exceeds the number of vacancies, all vacancies are filled and vice versa.

\subsection{Match requirements}

A match between a worker and an employer requires mutual agreement. This mutual agreement requires two conditions:

$$
\begin{aligned}
& C 1: E_{l} w\left(\alpha_{z}, l\right)-c_{l} \geq w\left(\alpha_{z}^{-}, l\right), \\
& C 2: E_{l} r\left(a_{z}, l\right)-c_{l} \geq r\left(a_{z}^{-}, l\right) .
\end{aligned}
$$

Condition $\mathrm{C} 1$ is the condition under which a worker in segment $z$ is willing to accept a job with complexity $\alpha_{z}$. The expected net wage of the job should equal or exceed the expected income of the least complex job of the segment in the countryside. Condition C2 states that an employer holding a vacancy in segment $z$ should be willing to let a worker with skills $a_{z}$ perform the job. The revenue generated by the worker should equal or exceed the revenue of employing the least skilled worker in the countryside.

All job seekers face the same problem: the wage of the job with the lowest complexity they accept equals that of the least complex job of their segment performed in the countryside. The upper bound is formed by the job with the highest complexity and wage they are able to obtain. Hence, workers would accept a job in a higher segment. Condition 2 states, however, that an employer would not hire a worker from a lower segment. The range of job possibilities for a worker with skills $a$ in segment $z$ is bounded. The lower bound of the set of jobs for which a worker is willing to settle is bound by the lower bound 
$\alpha_{z}^{-}$of matches and the upper bound $\alpha_{z}^{+}$. The upper bound sets the job with the highest complexity the worker is able to obtain. The lower bound is the complexity for which condition $\mathrm{C} 1$ is just violated, while the upper bound is the highest complexity for which condition $\mathrm{C} 2$ holds. The range of possibilities reflects the jobs for which the worker is willing to settle (C1) and able to obtain (C2). The worker searches in the job set $\alpha \in\left[\alpha_{z}^{-}, \alpha_{z}^{+}\right]$. Employers in the same segment $z$ face a similar problem and search for workers in the set $a \in\left[a_{z}^{-}, a_{z}^{+}\right]$.

Figure 1 displays the labour market set-up. Workers are ranked by their skills on the horizontal axis and jobs are ranked by their complexity on the vertical axis. The diagonal represents optimal matches between worker skills and job complexity. The squares represent the market segments. For instance, the first square consists of all low-educated workers and all jobs for low-educated workers. All low-educated workers search for a job within the set of low-educated jobs, which are labelled as low educated and attract only low-educated workers. The label of low educated does not tell the whole story, however. Within the group of low-educated workers, skills vary. Although they are both low-educated, worker B has more skills than worker A, for example. Similarly, the complexity of jobs within the low-educated group varies and job $\mathrm{Y}$ is more complex than job X.

\subsection{Match quality}

The number of matches within a location and segment affects the quality of the match between worker skills and job complexity. Within a market with many matches, both agents have more match choices than in a low-density market. Since both parties maximise their utility, the distance between worker skills and job complexity is as small as possible. The density of vacancies and job seekers is higher in the city than in the countryside and both workers and employers are choosier in the city. Therefore, we assume the

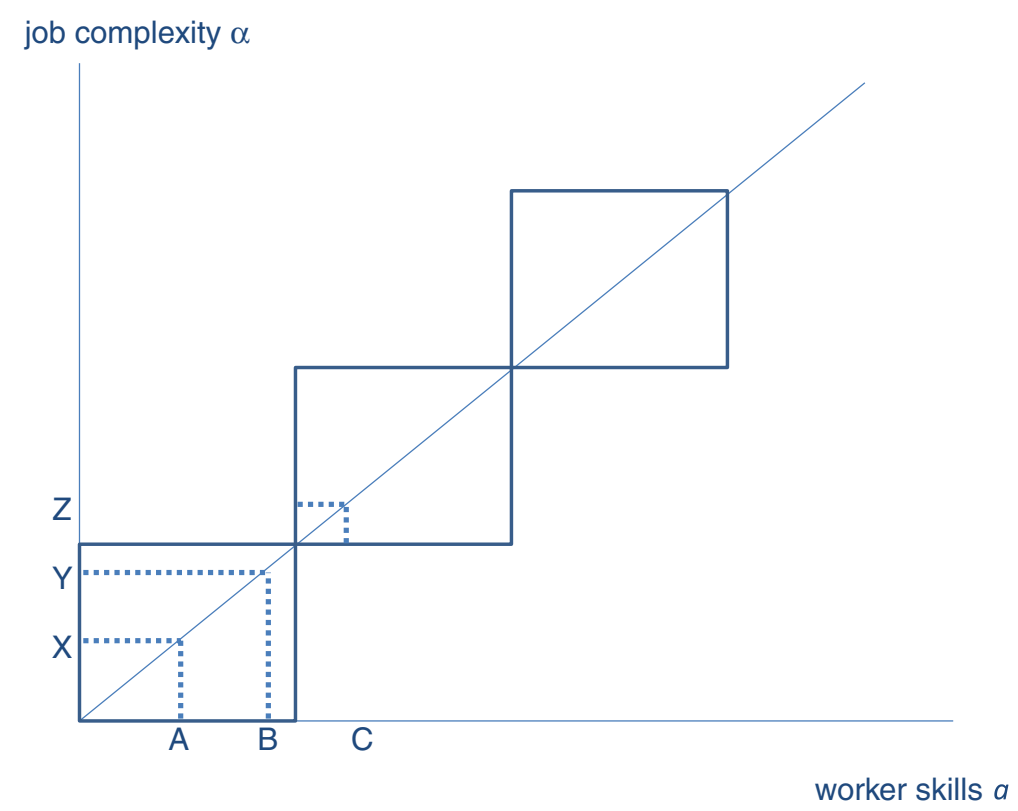

Figure 1 Matching. 
expected distance between complexity and skills to decrease with the number of matches in the market:

$$
E\left(\alpha_{z, l}-a_{z, l}\right)=\frac{1}{E\left(Q_{z, l}\right)}=\frac{1}{m_{z, l}}=\frac{1}{\min \left(S_{z, l}, V_{z, l}\right)},
$$

where $Q_{z, l}$ is the quality of the matches in segment $z$ in location $l$. The intuition is simple: the chance of a worker having the required job skills is smaller in a thin market than in a thick market. When there are only a few workers and vacancies, the match of a worker to a job becomes less efficient.

The spatial variation in match quality results in spatial variation in the expected wage of a worker with skills $a$ in segment $z$. In a market with better match quality, the gap between worker skills and job complexity is smaller. The thinner the market, the more friction within the matches and the less the expected wage depends on the worker's skills. Following this intuition, we assume

$$
E_{l}\left[w\left(\alpha_{z}, l\right)-w\left(\alpha_{z}^{-}\right)-c_{l}\right]=\left(a_{z}-a_{z}^{-}\right)^{E\left(Q_{z, l}\right)}+\delta^{1-E\left(Q_{z, l}\right)},
$$

where $w\left(\alpha_{z}, l\right)$ is the expected wage for segment $z$ at location $l$ and $w\left(\alpha_{z}^{-}\right)$is the minimum segment wage. The expected wage in a location depends on the worker skills and the match quality and costs of the location. The term $\left(a_{z}-a_{z}^{-}\right)^{E\left(Q_{z, l}\right)}$ defines the part of the expected wage that depends on worker skills, namely, the skill difference between a worker and the least skilled worker in the same segment. The better the match quality in the location, the more the wage depends on the skill difference. The term $\delta^{1-E\left(Q_{z, l}\right)}$ defines a randomly assigned additional wage caused by the sub-optimality of the matches in the location. The more agents in market $z, l$, the smaller the distance between skills and complexity and the more the wage difference reflects the skill difference; the importance of $\left(a_{z}-a_{z}^{-}\right)$increases with $E\left(Q_{z, l}\right)$. The rest of the wage, $\delta^{1-E\left(Q_{z, l}\right)}$, is a randomly assigned disturbance term caused by a mismatch due to the friction. ${ }^{8}$ As explained above, we assume the quality of the match to be better in the city and the impact of the friction to be larger in the countryside: $Q_{1}>Q_{0}>0$ for all segments $z$.

The expected revenue for an employer with a vacancy with complexity $\alpha$ in segment $z$ varies across the two locations and is defined similarly:

$$
E_{l}\left[r\left(a_{z, l}\right)-r\left(a_{z}^{-}\right)-c_{l}\right]=\left(\alpha_{z}-\alpha_{z}^{-}\right)^{E\left(Q_{z, l}\right)}+\delta^{1-E\left(Q_{z, l}\right)},
$$

where $\alpha_{z}-\alpha_{z}^{-}$is the difference in complexity between the job and the least complex job in the same segment.

\subsection{Location choice}

Both workers and employers choose their location before the matching moment. Workers maximise their nominal wage (Equation (3)) given the conditions $\mathrm{C} 1$ and $\mathrm{C} 2$ and expected wages at both locations (Equation (9)). A worker with skills $a$ in segment $z$ maximises

$$
E_{l} w\left(a_{z}\right)=\left(a_{z}-a_{z}^{-}\right)^{E\left(Q_{z, l}\right)}+\delta^{1-E\left(Q_{z, l}\right)}-c_{l} .
$$

The ratio between the expected nominal wage in the city and in the countryside is therefore:

$$
\frac{E_{1} w\left(a_{z}\right)}{E_{0} w\left(a_{z}\right)}=\frac{\left(a_{z}-a_{z}^{-}\right)^{E\left(Q_{1, z}\right)}-\Delta c}{\left(a_{z}-a_{z}^{-}\right)^{E\left(Q_{0, z}\right)}} .
$$


There is a trade-off between the better matching in the city, $\left(Q_{1, z}>Q_{0, z}\right)$, and the additional costs $\Delta c$ of working there. Because the expected value of the disturbance term $\delta$ is zero, this term does not affect the trade-off. The relative nominal wage in the city increases with worker skills $a_{z}$. However, location costs are higher in the city $(\Delta c)$ in decrease the nominal city wage. Workers who are relatively skilled, given their segment, benefit more from the better matching in the city than less skilled workers do in their segment. Hence, the less skilled a worker is, the lower the additional costs $\Delta c$ need to be to locate in the countryside. At a given $\Delta c$, there exists a value $a_{z}^{*}$ for which all workers with $a_{z}<a_{z}^{*}$ locate in the countryside and all workers with skills $a_{z}>a_{z}^{*}$ locate in the city.

Employers maximise their revenue at a location (Equation (4)) given the conditions C1 and $\mathrm{C} 2$ and expected revenues at both locations (Equation (10)). An employer with a vacancy with complexity $\alpha$ in segment $z$ maximises

$$
E_{l} r\left(\alpha_{z, l}\right)=\left(\alpha_{z}-\alpha_{z}^{-}\right)^{E\left(Q_{z, l}\right)}+\delta^{1-E\left(Q_{z, l}\right)}-c_{l} .
$$

The ratio between the expected nominal revenue in the city and in the countryside is

$$
\frac{E_{1} r\left(\alpha_{z}\right)}{E_{0} r\left(\alpha_{z}\right)}=\frac{\left(\alpha_{z}-\alpha_{z}^{-}\right)^{E\left(Q_{1, z}\right)}-\Delta c}{\left(\alpha_{z}-\alpha_{z}^{-}\right)^{E\left(Q_{0, z}\right)}}
$$

Employers face a similar trade-off between the better matching in the city $\left(Q_{z, 1}>Q_{z, 0}\right)$ and the additional costs $\Delta c$ of working in the city. Similar to the worker's problem, the less complex a job, the lower the additional location costs $\Delta c$ need to be for the employer to locate in the countryside. At a given $\Delta c$, there exists a value $\alpha_{z}^{*}$ for which all vacancies with $\alpha_{z}<\alpha_{z}^{*}$ locate in the countryside and all vacancies with complexity $\alpha_{z}>\alpha_{z}^{*}$ locate in the city.

As for Gautier et al. (2010), there is an elite city ordering ${ }^{9}$ : the better workers and more difficult jobs locate in the city to benefit from the better matching because their opportunity costs are higher. Note that in this model the elite ordering occurs within segments (e.g. education groups) and not between for example low and high educated workers.

Again, Figure 1 illustrates this mechanism. Workers A and B both search for a job in the lowest segment, segment 1 . Since worker B has more skills than worker A $\left(a_{1}^{B}>a_{1}^{A}\right)$, in an optimal match worker B's wage is higher than the one of worker $A$. The distance between worker B's optimal wage and the minimum wage in the segment is higher than that worker A. Worker B has therefore more wage to lose in a thin market than worker A and more incentive to locate in the city than worker A. Worker $C$ has more skills than worker $\mathrm{B}$ but operates in another segment. The difference between the optimal and minimum segment wages of worker $\mathrm{C}$ is lower than for worker $\mathrm{B}$. Although worker $\mathrm{C}$ has more skills, worker C's wage depends less on the tightness of the match than the wage of worker B. Worker $\mathrm{B}$ has the strongest incentive of workers $\mathrm{A}, \mathrm{B}$, and $\mathrm{C}$ to locate in the city with a high $Q_{z, l}$.

\subsection{Empirical predictions}

The model suggests that the higher density in cities results in more productive and tighter matches. Workers with higher skills and employers with more complex vacancies have 
higher opportunity costs, because they simply have more to lose. In summary, the model results in three hypotheses:

1. Matches between worker skills and job complexity are better in the city than in the countryside. Equation (8) states

$$
E\left(Q_{z, l}\right)=\min \left(S_{z, l}, V_{z, l}\right) \text { and thus } E\left(Q_{z, 1}\right)>E\left(Q_{z, 0}\right)
$$

where $l$ reflects the binary location choice between the city and the countryside.

2. Skilled workers are found more often in the city than in the countryside. Equation (12) implies a positive relation between skills and the wage difference between the city and the countryside:

$$
\frac{\partial E \Delta w}{\partial a_{z}}>0
$$

where $E \Delta w=E w_{1, z}-E w_{0, z}$ reflects the expected wage difference between the locations as defined in Equation (12). The larger wage difference between locations results in a positive relation between worker skill level and city location since the cost differences are compensated more:

$$
E\left(a_{z, 1}\right)>E\left(a_{z, 0}\right)
$$

3. More complex jobs are found more often in the city than in the countryside. Equation (14) implies a positive relation between skills and revenue difference between the city and the countryside:

$$
\frac{\partial E \Delta r}{\partial \alpha_{z}}>0,
$$

where $E \Delta r=E r_{1, z}-E r_{0, z}$ reflects the expected revenue difference between the locations as defined in Equation (14). Similar to the case of skilled workers, this results in a positive relation between job complexity and city location:

$$
E\left(\alpha_{z, 1}\right)>E\left(\alpha_{z, 0}\right)
$$

\section{Empirical strategy}

\subsection{Data}

We employ the LISS panel to empirically test the theoretical framework. The LISS panel is the core element of a project titled 'Measurement and Experimentation in the Social Sciences' from the Dutch research institute CentERdata. The panel consists of 5,000 households, with a total of 8,000 individuals. This household sample is a true representation, obtained from the Dutch population register.

All panel members complete the questionnaires online and update their information monthly. Households without Internet access receive a computer with Internet access. About half of the yearly interview time is reserved for the longitudinal study. The other half is distributed among additional questionnaires from researchers. This paper uses data from one of these additional questionnaires: a survey about job tasks carried out in May 2012. The questionnaire aims to gain insight into the importance of job tasks, the location where workers learned these tasks, and how efficient workers are in performing these tasks. A total of 3,883 household members were asked to fill out the questionnaire, with a response rate of 71.6 percent (2,780 household members). 
We match additional personal and career information from several studies of the LISS panel; the background study, the work and schooling study, and the personality study to this dataset. We drop all skilled agricultural, fishery, and forestry workers, since the locations of these occupations depend on natural resources. Only 29 individuals in the sample hold a job in this occupational group. Missing information about matching is replaced with the answers to the same question from the work and schooling study. A total of 13 respondents provided no matching information and 136 respondents provided no skill information. The ratio of city to countryside work location does not vary across missing and non-missing observations.

A major issue with these kind of surveys is that workers may overestimate or underestimate their capabilities and job tasks. Autor and Handel (forthcoming) provide a detailed discussion on issues with subjective evaluation of workers on their skills and tasks. They argue that aggregate samples of subjective measurement would generate sensible task-content measures. Section 5.1 discusses the concerns with subjectivity in this study.

\subsection{Variables}

\subsubsection{Worker skills}

An education diploma displays the vast amount of skills a worker holds and defines the worker's segment. Skills tend to be occupation specific; therefore we also distinguish between broad occupational groups. The theoretical model suggests that worker skills vary among students within the same graduation class. Honours, such as student of the year, underline this assumption. Skill variation within an education segment is estimated by the worker's personality. The idea is that more ambitious workers tend to invest more in their own skills. Both cognitive and social skills seem to be important for job performance, as indicated by Heckman et al. (2006), Borghans et al. (2006), and Bacolod et al. (2009).

We measure cognitive investments by the inclusion of five survey statements about a worker's cognitive orientation (see Table 1). Scaling varies across statements, which we rescale into three categories: zero if the worker (strongly) disagrees, one if the worker is neutral, and two if the worker (strongly) agrees. The cognitive skills index is standardised with a mean of zero and a standard deviation of one. In the same spirit, we define the social capacity of workers, given their education. Workers with more socially oriented personalities will develop more suitable skills for the performance of social tasks. Table 1 presents the five social characteristics of our index. The index for social skills is standardised with a mean of zero and a standard deviation of one. ${ }^{10}$

\subsubsection{Job complexity}

The dataset does not contain employer information about vacancies or job characteristics. All job information is gathered from the worker. The indicated importance of several job tasks defines the job's complexity. Thus, we assume that workers in more complex jobs indicate higher task importance. ${ }^{11}$ We distinguish between tasks that are crucial or very important for a job (core tasks) and tasks that are moderately or barely important for a job (subtasks). A job's complexity increases with the amount of core tasks. Again, we distinguish between cognitive and social job requirements. Table 1 defines eight cognitive and eight social job tasks. These tasks form a cognitive task index and a social task index, both standardised with a mean of zero and a standard deviation of one. 
Table 1 Skill and task variables

\begin{tabular}{|c|c|}
\hline \multicolumn{2}{|c|}{ Cognitive skills: cognitively oriented personality statements } \\
\hline 1. & I like to have the responsibility of handling a situation that requires a lot of thinking. \\
\hline 2. & I prefer complex problems to simple problems. \\
\hline 3. & I enjoy tasks that involve coming up with good solutions for new problems. \\
\hline 4. & I prefer my life to be filled with puzzles that I must solve. \\
\hline 5. & The notion of thinking abstractly is appealing to me. \\
\hline \multicolumn{2}{|c|}{ Social skills: socially oriented personality statements } \\
\hline 1. & I'm interested in other people. \\
\hline 2. & I make people feel at ease. \\
\hline 3. & I have social recognition. \\
\hline 4. & I start conversations. \\
\hline 5. & I feel comfortable around other people. \\
\hline \multicolumn{2}{|c|}{ Cognitive tasks } \\
\hline 1. & Knowledge of use or operation of tools/equipment machinery. \\
\hline 2. & Solving problems. \\
\hline 3. & Analysing problems. \\
\hline 4. & Planning the work of others. \\
\hline 5. & Reading long documents. \\
\hline 6. & Writing long documents with correct spelling and grammar. \\
\hline 7. & Simple calculations. \\
\hline 8. & Calculations with math and/or statistics. \\
\hline \multicolumn{2}{|c|}{ Social tasks } \\
\hline 1. & Dealing with people. \\
\hline 2. & Working together or in a team. \\
\hline 3. & Listening to other people. \\
\hline 4. & Teaching people. \\
\hline 5. & Making speeches/presentations. \\
\hline 6. & Selling a product or service. \\
\hline 7. & Persuading or influencing others. \\
\hline 8. & Counselling, advising, or caring for customers or clients. \\
\hline
\end{tabular}

\subsubsection{Matching}

Match quality defines the gap between worker skills and job complexity: $\alpha_{z}-a_{z}$, as defined in Section 2. The smaller the gap between these two, the better the match. First, we include the question 'How do your knowledge and skills suit the work you do?'. The answer choices range from zero (do not suit my work at all) to 100 (suit my work perfectly). Both the survey about job tasks and the work and schooling study include this question. When the answers differ between the two questions, we use the mean of the two. ${ }^{12}$ The second quality measure considers the gap between the importance of cognitive (social) job tasks and the worker's invested skills in such cognitive (social) tasks. The smaller the gap between the (standardised) importance and (standardised) skills, the better the worker is suited for the job. For comparability, we standardise the matching indexes.

\subsubsection{Location}

The questionnaire includes two questions about location, one about the location of residence and the other about the work location. Both questions indicate the urban character of the location by its density. Five categories are distinguished by the amount of 
dwellings per square kilometre: extremely urban (more than 2,500 dwellings), very urban (1,500-2,500 dwellings), moderately urban (1,000-1,500 dwellings), slightly urban (500-1,000 dwellings), and not urban (fewer than 500 dwellings). In line with the theoretical model, we distinguish a city labour market and a countryside labour market. We generate a city dummy indicating whether the place of work consists of more than 1,500 dwellings per square kilometre.

\subsubsection{Additional variables}

Besides urban character, job complexity, worker skills, and the matching between these two, we include personal characteristics and wage information. Table 2 gives an overview of the dependent variables, while Table 14 in Appendix A presents all the variables, measurements, and summary statistics.

\subsection{Descriptive statistics}

Tables 3 presents simple descriptive statistics for our dataset. On average, workers rate the suitability of their skills for their job as 69.86 on a scale of zero to 100, with a standard deviation of 20.09. This indicated suitability is higher among high-skilled workers and workers in cities than across low- and middle-skilled workers and workers located in the countryside. The matching of cognitive skills to cognitive job tasks shows a similar pattern. The cognitive skills of high-skilled workers match their cognitive job tasks better than the skills of low- and middle-skilled workers do. The cognitive job matches are better in the city than in the countryside. Table 15 in Appendix A shows significant spatial variation. The tables also show a less clear pattern of the matching of social job tasks across skill groups and working locations. Table 4 presents the summary statistics by broad occupational groups. Professionals enjoy, on average, the best assignment of skills to jobs, while workers in elementary jobs indicate the worst matches. For cognitive skills the match is especially strong among managers and weak among operators and within elementary occupations.

Table 2 Job content variables

\begin{tabular}{ll}
\hline Matching all skills & Matching variables \\
Cognitive skills \& cognitive tasks & \begin{tabular}{l} 
How do your knowledge and skills suit the work you do? \\
Absolute difference between cognitive skills and cognitive task \\
importance (see below). \\
Social skills \& cognitive tasks \\
\hline Absolute difference between social skills and social task importance \\
(see below).
\end{tabular} \\
\hline Investment cognitive skills & $\begin{array}{l}\text { Score on } 5 \text { statements about cognitively oriented personality - see } \\
\text { Table 1. } \\
\text { Investment social skills }\end{array}$ \\
\hline Score on 5 statements about socially oriented personality - see \\
Table 1.
\end{tabular}

Note: the definitions and measurement of the variables are displayed in Table 14 in Appendix A. 
Table 3 Match quality, skills, and job tasks by education group and location

\begin{tabular}{|c|c|c|c|c|c|c|c|c|c|c|c|c|c|}
\hline & \multirow[b]{2}{*}{ Observations } & \multicolumn{2}{|c|}{ Crude } & \multicolumn{2}{|c|}{ Low skilled } & \multicolumn{2}{|c|}{ Medium skilled } & \multicolumn{2}{|c|}{ High skilled } & \multicolumn{2}{|c|}{ Countryside } & \multicolumn{2}{|c|}{ City } \\
\hline & & Mean & SD & Mean & SD & Mean & SD & Mean & SD & Mean & SD & Mean & SD \\
\hline \multicolumn{14}{|c|}{ Matching variables } \\
\hline Matching all skills & 2,373 & 0.70 & $(0.20)$ & -0.08 & $(0.06)$ & 0.15 & $(0.04)$ & 0.35 & $(0.03)$ & 0.13 & $(0.03)$ & 0.25 & $(0.03)$ \\
\hline Cognitive skills \& cognitive tasks & 1,596 & 0.93 & $(0.75)$ & -0.12 & $(0.05)$ & -0.09 & $(0.04)$ & 0.14 & $(0.04)$ & -0.06 & $(0.03)$ & 0.07 & $(0.04)$ \\
\hline Social skills \& cognitive tasks & 1,596 & 1.00 & $(0.75)$ & 0.06 & $(0.06)$ & -0.05 & $(0.04)$ & 0.03 & $(0.04)$ & -0.01 & $(0.03)$ & 0.01 & $(0.04)$ \\
\hline \multicolumn{14}{|c|}{ Skill variables } \\
\hline Investment in cognitive skills & 2,149 & 0.23 & $(0.27)$ & -0.28 & $(0.04)$ & -0.14 & $(0.04)$ & 0.34 & $(0.05)$ & -0.08 & $(0.03)$ & 0.15 & $(0.04)$ \\
\hline Investment in social skills & 2,149 & 0.18 & $(0.23)$ & -0.07 & $(0.05)$ & -0.04 & $(0.04)$ & 0.10 & $(0.04)$ & -0.08 & $(0.03)$ & 0.10 & $(0.04)$ \\
\hline \multicolumn{14}{|c|}{ Task variables } \\
\hline Importance of cognitive tasks & 1,724 & 0.33 & $(0.26)$ & -0.42 & $(0.05)$ & -0.11 & $(0.04)$ & 0.30 & $(0.04)$ & -0.11 & $(0.03)$ & 0.11 & $(0.04)$ \\
\hline Importance of social tasks & 1,724 & 0.48 & $(0.27)$ & -0.32 & $(0.06)$ & -0.12 & $(0.04)$ & 0.27 & $(0.04)$ & -0.10 & $(0.04)$ & 0.11 & $(0.04)$ \\
\hline
\end{tabular}

Note: the definitions and measurement of the variables are displayed in Table 14 in Appendix A. 
Table 4 Matching skills and tasks across occupations

\begin{tabular}{|c|c|c|c|c|c|c|c|c|c|c|c|c|c|c|c|c|}
\hline & \multicolumn{2}{|c|}{ 1. Managers } & \multicolumn{2}{|c|}{ 2. Professionals } & \multicolumn{2}{|c|}{ 3. Technicians } & \multicolumn{2}{|c|}{ 4. Clerks } & \multicolumn{2}{|c|}{ 5. Service and sales } & \multicolumn{2}{|c|}{ 7. Craft and trade } & \multicolumn{2}{|c|}{ 8. Operators } & \multicolumn{2}{|c|}{ 9. Elementary } \\
\hline & Mean & SD & Mean & SD & Mean & SD & Mean & SD & Mean & SD & Mean & SD & Mean & SD & Mean & SD \\
\hline \multicolumn{17}{|c|}{ Matching variables } \\
\hline Matching all skills & 0.22 & $(0.91)$ & 0.25 & $(0.76)$ & 0.14 & $(0.84)$ & -0.22 & $(1.07)$ & -0.29 & $(1.16)$ & 0.03 & $(0.97)$ & -0.15 & $(1.11)$ & -0.71 & $(1.33)$ \\
\hline Cognitive skills \& cognitive tasks & 0.18 & $(1.16)$ & 0.05 & $(1.04)$ & 0.05 & $(0.98)$ & -0.15 & $(0.82)$ & -0.07 & $(0.99)$ & -0.12 & $(0.98)$ & -0.24 & $(0.87)$ & 0.12 & $(1.04)$ \\
\hline Social skills \& cognitive tasks & 0.09 & $(0.99)$ & 0.00 & $(0.99)$ & 0.01 & $(1.01)$ & -0.16 & $(0.93)$ & 0.05 & $(0.97)$ & 0.19 & $(1.25)$ & -0.09 & $(0.85)$ & 0.08 & $(1.06)$ \\
\hline \multicolumn{17}{|c|}{ Skill variables } \\
\hline Investment in cognitive skills & 0.46 & $(1.16)$ & 0.21 & $(1.09)$ & -0.10 & $(0.95)$ & -0.15 & $(0.84)$ & -0.23 & $(0.90)$ & -0.13 & $(0.87)$ & -0.37 & $(0.63)$ & -0.25 & $(0.81)$ \\
\hline Investment in social skills & 0.19 & $(1.10)$ & 0.06 & $(1.02)$ & 0.05 & $(1.02)$ & -0.15 & $(0.93)$ & -0.01 & $(0.99)$ & -0.07 & $(1.00)$ & -0.25 & $(0.69)$ & -0.08 & $(0.96)$ \\
\hline \multicolumn{17}{|c|}{ Job tasks } \\
\hline Importance of cognitive tasks & 0.54 & $(1.07)$ & 0.18 & $(0.97)$ & 0.10 & $(1.00)$ & -0.22 & $(0.89)$ & -0.34 & $(0.93)$ & -0.13 & $(0.85)$ & -0.53 & $(0.93)$ & -0.64 & $(0.83)$ \\
\hline Importance of social tasks & 0.48 & $(0.94)$ & 0.23 & $(0.91)$ & 0.08 & $(0.92)$ & -0.33 & $(0.92)$ & -0.02 & $(1.02)$ & -0.67 & $(1.03)$ & -0.56 & $(1.05)$ & -0.55 & $(1.03)$ \\
\hline
\end{tabular}

Note: we use one-digit ISCO occupations. The occupation group of skilled agricultural, fishery, and forestry workers is omitted since the location of these occupations depends on natural resources. The definitions and measurement of the variables are displayed in Table 14 in Appendix A. 
A worker's cognitive skill level is estimated by the number of cognitive statements with which the worker agrees or strongly agrees, on average, 0.23 out of 5 . High-skilled workers agree with more statements than low- and middle-skilled workers. Respondents who work in the city have more cognitively oriented personalities than respondents who work in the countryside. The same pattern is apparent for social skills. Managers have the most cognitive and social skills according to themselves, while operators attribute the least skills to themselves.

The last two rows of the table show the summary statistics of core cognitive and core social job tasks. Of the five possible core cognitive job tasks, workers, on average, indicate that their job consists of 0.33 . For core social job tasks, this average is 0.48 . Similar to cognitive and social skills, high-skilled workers and workers in cities perform more cognitive and social job tasks than low- and middle-skilled workers and workers in the countryside. Again, managers state that their job contains the most cognitive and social job tasks, while elementary workers and operators indicate that their jobs contain the fewest.

As in Teulings (1995), personal characteristics correlate with job characteristics. More cognitive oriented persons perform more cognitive tasks (correlation 0.30, significant at the $1 \%$ level) while more social oriented persons perform more social tasks (correlation 0.20 , significant at the $1 \%$ level). These correlations are stronger in the city than in the countryside. Table 15 shows no significant correlation between the indexes for match quality. The matches of skills to tasks are better for workers with more skills and more complex jobs. The positive and significant correlation with gross monthly earnings suggests that better matches lead to higher wages.

\subsection{Empirical model}

The theoretical model results in empirical predictions about the distribution of match quality, worker skills, and job complexity across location $L$. We define a simple empirical strategy following Equations (15) to (19) to test these predictions:

$$
y_{i, l}=\alpha_{0}+\alpha_{1} L_{l}+\alpha_{2} E_{i}+\alpha_{3} Z_{i},+\epsilon_{i, l},
$$

where $y_{i, l}$ is the dependent variable for worker $i$ in location $l$ and reflects either match quality $Q_{i, l}$, skill level $a_{i, l}$, or job complexity $\alpha_{i, l}$. The term $L_{l}$ is a dummy variable indicating whether the worker works in the city or the countryside. This dummy captures the impact of the local mass of vacancies and job seekers $\left(\min \left(U_{z, l}, V_{z, l}\right)\right)$. The worker's segment, $z$, is defined by the worker's educational background $\left(E_{i}\right)$ and demographic characteristics $\left(Z_{i}\right)$. The theoretical model assumes workers search for a job within their educational class. However, within educational classes, the task packages and skills required vary strongly between different fields. To control for this heterogeneity, we also estimate a model with standard errors clustered at one-digit occupations and a model with occupational fixed effects.

Several measurement issues can affect the estimation of this empirical model. First, our dataset is a self-reporting survey, which can lead to measurement error. Measurement error affects our results when the error varies between countryside and cities. We have no reason to expect such a spatial variation. Second, the spatial sorting of workers may be driven by certain consumption preferences (e.g., Glaeser and Gottlieb (2006)). If this is the case, our estimates of matching and sorting reflect a sorting pattern of workers for consumption instead of for job opportunities. Third, the strong regional differences in 
the Netherlands, especially that between the Randstad area and the other regions, can result in biased results for the sample of all regions. Fourth, higher skill levels in cities may reflect a more efficient learning mechanism in cities instead of the sorting of more skilled workers into cities. In line with this reasoning, our results could show additional learning effects of city locations. Different segments may also face different types of labour market frictions. Lastly, the unequal spatial distribution of industrial and service sectors may drive the results, since these sectors have different location advantages and different production structures. Section 5 discusses these issues in detail and provides sensitivity analyses.

\section{Results}

\subsection{Match quality in cities}

The theoretical framework argues that the quality of the match of worker skills to job tasks increases with the density of the local market. Table 5 presents the results of estimating the empirical model with three measures of match quality. In the first column, the suitability of a worker's skills for a job is explained by location and demographic characteristics. The coefficient of the city dummy is positive and significant: suitability is better in thick labour markets than in thin ones in the Netherlands. Furthermore, the quality of the match increases with age: young workers indicate that their skills suit their job worse than older workers. During their careers, workers self-select into jobs that match their skills better as their knowledge of both their own skills and required job tasks increase with experience. On-the-job training and learning by doing likely improve the match as well. Matches are better for men than for women and better for native workers than for nonnative workers. The quality of the match increases with education level, which suggests that education is effective in terms of skill development.

Next, we cluster the standard errors for two-digit occupations (column (2)) and include fixed occupational effects (column (3)) to control for differences across education fields. Both worker skills and the task packages of jobs vary heavily between occupational groups. For instance, managers and clerks perform different tasks and therefore need different skills to perform their tasks. The coefficient of being located in a city remains significant and positive when we control for occupational differences. The match of worker skills to job tasks in cities is, on average, 14 percent of a standard deviation better than that of workers in the same occupational group in the countryside. In absolute terms, this finding is a difference of 2.8 points on a scale of zero to 100 . Column (4) shows that relatively skilled workers, given their segment, experience better matches than less skilled workers in their segment.

The second measure of assignment quality considers cognitive skills and cognitive job tasks. Workers who focus on a smaller subset of job tasks and are more specialised develop more specific skills (Becker and Murphy 1992). Furthermore, highly cognitive workers sort into specialised jobs (Bacolod et al. 2009). The higher the specialisation level of a worker and a job, the more difficulties arise with finding a decent match between the two. Among different skill types, cognitive skills seem to be an important measure for the relevance of the match. The match of cognitive skills to cognitive tasks is also significantly better in cities than in the countryside (column (5)). When we control for broad occupational groups, the city coefficient loses some significance but remains significant and positive (columns (6) and (7)). ${ }^{13}$ Workers with abundant cognitive skills face 
Table 5 Matching is better in cities

\begin{tabular}{|c|c|c|c|c|c|c|c|c|c|c|c|c|}
\hline & \multicolumn{12}{|c|}{ Match quality } \\
\hline & \multicolumn{4}{|c|}{ All skills } & \multicolumn{4}{|c|}{ Cognitive skills } & \multicolumn{4}{|c|}{ Social skills } \\
\hline & $(1)$ & (2) & (3) & $(4)$ & (5) & (6) & (7) & (8) & (9) & $(10)$ & $(11)$ & $(12)$ \\
\hline \multirow[t]{2}{*}{ City } & $0.146^{* * *}$ & $0.146^{* * *}$ & $0.136^{* * *}$ & $0.104^{* * *}$ & $0.095^{*}$ & $0.095^{*}$ & $0.093^{*}$ & 0.060 & 0.014 & 0.014 & 0.015 & -0.027 \\
\hline & {$[0.040]$} & {$[0.032]$} & {$[0.029]$} & {$[0.035]$} & {$[0.050]$} & {$[0.048]$} & {$[0.048]$} & {$[0.043]$} & {$[0.051]$} & {$[0.052]$} & {$[0.051]$} & {$[0.054]$} \\
\hline \multirow[t]{2}{*}{ Age } & $0.010^{* * *}$ & $0.010^{* * *}$ & $0.007^{* *}$ & $0.007^{* *}$ & -0.001 & -0.001 & -0.001 & -0.003 & -0.001 & -0.001 & -0.000 & 0.000 \\
\hline & {$[0.002]$} & {$[0.003]$} & {$[0.003]$} & {$[0.003]$} & {$[0.002]$} & {$[0.002]$} & {$[0.003]$} & {$[0.003]$} & {$[0.003]$} & {$[0.003]$} & {$[0.003]$} & {$[0.002]$} \\
\hline \multirow[t]{2}{*}{ Female } & $-0.075^{*}$ & -0.075 & -0.045 & -0.046 & $-0.114^{* *}$ & $-0.114^{* *}$ & -0.088 & -0.006 & -0.034 & -0.034 & 0.006 & -0.062 \\
\hline & {$[0.040]$} & {$[0.054]$} & {$[0.055]$} & {$[0.057]$} & {$[0.050]$} & {$[0.046]$} & {$[0.053]$} & {$[0.053]$} & {$[0.051]$} & {$[0.046]$} & {$[0.048]$} & {$[0.047]$} \\
\hline \multirow[t]{2}{*}{ Native } & $0.171^{* *}$ & $0.171^{* * *}$ & $0.150^{* *}$ & $0.174^{* * *}$ & -0.099 & -0.099 & -0.090 & -0.091 & $-0.169^{*}$ & -0.169 & -0.166 & -0.115 \\
\hline & {$[0.079]$} & {$[0.061]$} & {$[0.060]$} & {$[0.060]$} & {$[0.100]$} & {$[0.117]$} & {$[0.119]$} & {$[0.109]$} & {$[0.098]$} & {$[0.107]$} & {$[0.108]$} & {$[0.092]$} \\
\hline \multirow[t]{2}{*}{ Medium skilled } & $0.151^{* * *}$ & $0.151^{* * *}$ & 0.075 & 0.088 & 0.012 & 0.012 & -0.019 & -0.052 & -0.080 & -0.080 & -0.052 & -0.062 \\
\hline & [0.059] & {$[0.055]$} & {$[0.053]$} & {$[0.056]$} & {$[0.063]$} & {$[0.061]$} & {$[0.063]$} & {$[0.058]$} & {$[0.068]$} & {$[0.059]$} & {$[0.064]$} & {$[0.059]$} \\
\hline \multirow[t]{2}{*}{ High skilled } & $0.421^{* * *}$ & $0.421^{* * *}$ & $0.211^{* * *}$ & $0.204^{* *}$ & $0.226^{* * *}$ & $0.226^{* * *}$ & $0.151^{* *}$ & 0.020 & -0.002 & -0.002 & -0.013 & -0.032 \\
\hline & {$[0.054]$} & {$[0.057]$} & {$[0.071]$} & {$[0.074]$} & {$[0.066]$} & {$[0.066]$} & {$[0.067]$} & {$[0.068]$} & {$[0.070]$} & {$[0.065]$} & {$[0.072]$} & {$[0.082]$} \\
\hline \multirow[t]{2}{*}{ Cognitive skills } & & & & $0.079^{* * *}$ & & & & $0.279^{* * *}$ & & & & -0.022 \\
\hline & & & & {$[0.018]$} & & & & {$[0.038]$} & & & & {$[0.036]$} \\
\hline \multirow[t]{2}{*}{ Social skills } & & & & $0.046^{* *}$ & & & & -0.033 & & & & $0.336^{* * *}$ \\
\hline & & & & {$[0.019]$} & & & & {$[0.025]$} & & & & {$[0.052]$} \\
\hline \multirow[t]{2}{*}{ Constant } & $-0.761^{* * *}$ & $-0.761^{* * *}$ & $-0.537^{* *}$ & $-0.534^{* *}$ & 0.160 & 0.160 & 0.176 & 0.211 & 0.268 & 0.268 & 0.182 & 0.242 \\
\hline & {$[0.144]$} & {$[0.213]$} & {$[0.221]$} & {$[0.231]$} & {$[0.171]$} & {$[0.176]$} & {$[0.187]$} & {$[0.187]$} & {$[0.184]$} & {$[0.205]$} & {$[0.219]$} & {$[0.215]$} \\
\hline Clustered standard errors & & Yes & Yes & Yes & & Yes & Yes & Yes & & Yes & Yes & Yes \\
\hline Fixed effects & & & Yes & Yes & & & Yes & Yes & & & Yes & Yes \\
\hline Observations & 2,373 & 2,373 & 2,373 & 2,149 & 1,596 & 1,596 & 1,596 & 1,596 & 1,596 & 1,596 & 1,596 & 1,596 \\
\hline Adjusted R-squared & 0.053 & 0.053 & 0.017 & 0.027 & 0.016 & 0.016 & 0.007 & 0.074 & 0.001 & 0.001 & -0.001 & 0.101 \\
\hline
\end{tabular}

Note: the definitions and measurement of the variables are displayed in Table 14 in Appendix A. Robust or clustered standard errors are in parentheses. Fixed effects refer to those at the two-digit occupational level (ISCO codes). 
a better match to cognitive job tasks. A worker's social skills do not affect the cognitive match.

Economic activity in cities benefits from proximity, learning, and knowledge spillovers. Considering these advantages, skills that ease or improve communication and interactions with others are especially valued in cities (Bacolod et al. 2009). Furthermore, more social, non-cognitive skills determine labour market outcomes as well (e.g., Heckman et al. (2006)). Columns (9) to (12) of Table 5 show the estimates for the determinants of the assignment of social worker skills to social job tasks. The coefficient for working in a city is positive but insignificant. There is no significant spatial variation in the match quality of social skills to social job tasks. Workers with strong social skills have better matches than workers with few social skills.

\subsection{Worker skills and job tasks in cities}

The model suggests self-selection of more skilled workers and complex jobs into cities. Table 6 presents the results of an estimation of the spatial distribution of worker skills and job tasks. The cognitive interest of workers in cities is, on average, greater than that of workers in the countryside (column (1)). Column (2) clusters the standard errors by broad occupational groups and column (3) includes fixed effects at the occupational level. The coefficient for working in a dense urban area remains positive and significant. The spatial differences are substantial. City workers have a 14 percent of a standard deviation more cognitive skills than workers in the countryside. Given their job, older workers, males, and high-skilled workers have more cognitive skills than younger workers, females, and low-skilled workers.

Columns (4) to (6) present the same estimates for workers' social skills. Workers in cities have more social skills than workers in the countryside. The spatial variation of 10 percent of a standard deviation is somewhat smaller than that for cognitive skills. Females have more social skills, while males have more cognitive skills.

Not only better workers but also better jobs are expected to sort into cities. Here, we consider the importance of several cognitive and social tasks (defined in Section 3.2) in job complexity. Jobs in cities demand more cognitive core job tasks than jobs in the countryside (column (7)). Bacolod et al. (2009) find no such spatial differences. Since they only measure the average task package of occupations, this finding suggests spatial variation within the content of jobs. Columns (8) and (9) indeed show significant spatial variation in task packages within broad occupations. Occupations in cities contain 9 percent of a standard deviation more cognitive job tasks than the same occupation in the countryside. Column (10) shows that workers in cities perform more social job tasks than workers in the countryside. This spatial variation is, however, fully explained by the spatial distribution of jobs (column (11)).

\section{Further analyses}

Previous estimates may be affected by several estimation issues, as discussed in Section 3.4. To test the sensitivity of the results to these issues, this section presents several additional analyses. First, in Section 5.1 we test the impact of measurement error caused by the self-reporting of the main variables. Next, in Section 5.2 we test whether our results reflect the sorting of workers for job opportunities or for consumption preferences. Regional differences in local labour markets are analysed in Section 5.3. Fourth, 
Table 6 Spatial distribution skills and tasks

\begin{tabular}{|c|c|c|c|c|c|c|c|c|c|c|c|c|}
\hline & \multicolumn{3}{|c|}{ Cognitive skills } & \multicolumn{3}{|c|}{ Social skills } & \multicolumn{3}{|c|}{ Cognitive tasks } & \multicolumn{3}{|c|}{ Social tasks } \\
\hline & (1) & $(2)$ & (3) & (4) & (5) & (6) & (7) & $(8)$ & (9) & $(10)$ & (11) & (12) \\
\hline \multirow[t]{2}{*}{ City } & $0.159^{* * *}$ & $0.159^{* * *}$ & $0.137^{* * *}$ & $0.116^{* * *}$ & $0.116^{* * *}$ & $0.101^{* * *}$ & $0.127^{* * *}$ & $0.127^{* *}$ & $0.090^{*}$ & $0.122^{* *}$ & $0.122^{*}$ & 0.062 \\
\hline & {$[0.042]$} & {$[0.044]$} & {$[0.046]$} & {$[0.044]$} & {$[0.039]$} & {$[0.036]$} & {$[0.047]$} & {$[0.052]$} & {$[0.050]$} & {$[0.048]$} & {$[0.060]$} & {$[0.056]$} \\
\hline \multirow[t]{2}{*}{ Age } & $0.007^{* * *}$ & $0.007^{* * *}$ & $0.006^{* * *}$ & -0.001 & -0.001 & -0.002 & -0.001 & -0.001 & $-0.004^{* *}$ & 0.003 & $0.003^{*}$ & 0.000 \\
\hline & {$[0.002]$} & {$[0.002]$} & {$[0.002]$} & {$[0.002]$} & [0.002] & {$[0.002]$} & {$[0.002]$} & {$[0.002]$} & {$[0.002]$} & {$[0.002]$} & {$[0.002]$} & {$[0.002]$} \\
\hline \multirow[t]{2}{*}{ Female } & $-0.296^{* * *}$ & $-0.296^{* * *}$ & $-0.242^{* * *}$ & $0.174^{* * *}$ & $0.174^{* * *}$ & $0.177^{* * *}$ & $-0.306^{* * *}$ & $-0.306^{* * *}$ & $-0.246^{* * *}$ & 0.024 & 0.024 & $-0.098^{* *}$ \\
\hline & {$[0.041]$} & {$[0.045]$} & {$[0.042]$} & {$[0.043]$} & {$[0.050]$} & {$[0.053]$} & {$[0.046]$} & {$[0.051]$} & {$[0.047]$} & {$[0.047]$} & {$[0.085]$} & {$[0.045]$} \\
\hline \multirow[t]{2}{*}{ Native } & -0.007 & -0.007 & -0.020 & $-0.161^{* *}$ & $-0.161^{*}$ & $-0.160^{*}$ & 0.017 & 0.017 & -0.010 & 0.108 & 0.108 & 0.059 \\
\hline & {$[0.067]$} & {$[0.075]$} & {$[0.075]$} & {$[0.080]$} & {$[0.090]$} & {$[0.088]$} & {$[0.086]$} & {$[0.072]$} & {$[0.069]$} & {$[0.084]$} & {$[0.072]$} & {$[0.063]$} \\
\hline \multirow[t]{2}{*}{ Medium skilled } & $0.199^{* * *}$ & $0.199^{* * *}$ & $0.161^{* * *}$ & -0.003 & -0.003 & -0.016 & $0.283^{* * *}$ & $0.283^{* * *}$ & $0.124^{* *}$ & $0.205^{* * *}$ & $0.205^{* *}$ & 0.070 \\
\hline & {$[0.046]$} & {$[0.053]$} & {$[0.049]$} & {$[0.055]$} & {$[0.060]$} & {$[0.055]$} & {$[0.062]$} & {$[0.057]$} & [0.049] & {$[0.069]$} & {$[0.075]$} & {$[0.057]$} \\
\hline \multirow[t]{2}{*}{ High skilled } & $0.625^{* * *}$ & $0.625^{* * *}$ & $0.508^{* * *}$ & $0.147^{* * *}$ & $0.147^{* *}$ & 0.076 & $0.639^{* * *}$ & $0.639^{* * *}$ & $0.362^{* * *}$ & $0.548^{* * *}$ & $0.548^{* * *}$ & $0.232^{* * *}$ \\
\hline & {$[0.051]$} & {$[0.073]$} & {$[0.069]$} & {$[0.056]$} & {$[0.056]$} & {$[0.053]$} & {$[0.062]$} & {$[0.077]$} & {$[0.063]$} & {$[0.067]$} & {$[0.101]$} & {$[0.082]$} \\
\hline \multirow[t]{2}{*}{ Constant } & $-0.229^{*}$ & $-0.229^{* *}$ & $-0.195^{*}$ & -0.196 & -0.196 & -0.106 & 0.051 & 0.051 & $0.337^{* *}$ & $-0.637^{* * *}$ & $-0.637^{* * *}$ & -0.071 \\
\hline & {$[0.128]$} & {$[0.101]$} & {$[0.107]$} & {$[0.144]$} & {$[0.136]$} & {$[0.127]$} & {$[0.156]$} & [0.182] & {$[0.161]$} & {$[0.167]$} & {$[0.193]$} & {$[0.118]$} \\
\hline Clustered standard errors & & Yes & Yes & & Yes & Yes & & Yes & Yes & & Yes & Yes \\
\hline Fixed effects & & & Yes & & & Yes & & & Yes & & & Yes \\
\hline Observations & 2,149 & 2,149 & 2,149 & 2,149 & 2,149 & 2,149 & 1,724 & 1,724 & 1,724 & 1,724 & 1,724 & 1,724 \\
\hline Adjusted R-squared & 0.106 & 0.106 & 0.054 & 0.016 & 0.016 & 0.010 & 0.093 & 0.093 & 0.035 & 0.053 & 0.053 & 0.09 \\
\hline
\end{tabular}

Note: cognitive (social) skills refer to the number of cognitive (social) statements the respondent agrees with. Cognitive (social) tasks refer to the number of cognitive (social) tasks the worker performs. The definitions and measurement of the variables are displayed in Table 14 in Appendix A. Robust or clustered standard errors are in parentheses. Fixed effects refer to those at the two-digit occupational level (ISCO codes). 
Section 5.4 discusses the role of quicker human capital accumulation in cities. Section 5.5 presents separate analyses for industrial and service occupations and Section 5.6 for low, middle and high-skilled workers. Lastly, Section 5.7 presents a first indicator for the relevance of match quality in urban wage premia. Here, we only present the results for one measure of match quality, namely, the suitability of all skills. The quality of the cognitive match shows similar patterns, with less significant spatial variation. Social match quality never shows significant spatial variation.

\subsection{Subjective measurement}

The dataset consists of self-reported personalities, self-reported job tasks, and selfreported quality of job matches. Autor and Handel (forthcoming) discuss several issues with this kind of survey. Bias caused by the respondents' subjective answers is our main concern. First, bias can result from the abstract definitions of the variables, resulting in different interpretations among respondents. Second, respondents likely vary in how they distribute scores. For instance, some respondents will label a score as important, whereas others will label the same score as very important. Third, workers may over or underestimate their own skills, jobs tasks and job match, e.g. be 'overconfident'. This measurement error affects our results when workers in cities have different biases in their answers than workers in the countryside.

The survey includes questions about task importance and the effectiveness of several tasks for commonly known example jobs. All respondents should have an image of the task package and required skills of these well-known jobs, such as secretary or teacher. The questions measure the respondent's answering bias. The idea is that when a respondent interprets a certain task differently or provides higher scores than others, he or she will do so for the example job as well. We use the relative answers of respondents to proxy for answering bias in match, skill, and task questions. The relative answers about the effectiveness of workers in certain tasks in the example jobs proxy for measurement error in skills, while the relative answers about the importance of tasks proxy for errors in relevance of job tasks. Lastly, the error in a match is proxied for by the difference between relative importance and relative effectiveness. Appendix B displays the details of the measurement.

The average value of all three proxies is significantly higher in cities than in the countryside. Workers who work in cities attribute relatively more importance, more effectiveness, and better match quality between importance and effectiveness to the job tasks of example jobs. This spatial variation could be driven by different worker attitudes in cities and the spatial sorting of workers. The value of all three proxies also varies significantly across education groups. We test the impact of this spatial variation in measurement error in two steps. First, we test whether the spatial variation remains significant when we control for other characteristics, such as education and gender. Second, we include the proxy in our baseline empirical model to see whether the results change when we control for measurement error.

The first three columns of Table 7 show the spatial variation in these three proxies, controlling for the usual factors. Only the spatial variation of attributing effectiveness to a task in an example job remains significant when we control for other characteristics. This finding suggests that measurement error could affect our measure of the sorting of skilled workers in cities, but probably not that of match quality. Columns (4) 
Table 7 Subjective measurement

\begin{tabular}{|c|c|c|c|c|c|c|c|c|}
\hline & \multicolumn{3}{|c|}{ Measurement error proxy } & \multirow[t]{2}{*}{ Matching } & \multicolumn{2}{|c|}{ Skills } & \multicolumn{2}{|c|}{ Tasks } \\
\hline & Imp-eff & Effectiveness & Importance & & Cognitive & Social & Cognitive & Social \\
\hline & $(1)$ & (2) & (3) & (4) & $(5)$ & (6) & (7) & (8) \\
\hline \multirow[t]{2}{*}{ City } & -0.003 & 0.082 & 0.079 & $0.105^{* * *}$ & $0.113^{* *}$ & $0.125^{* * *}$ & 0.083 & 0.053 \\
\hline & {$[0.036]$} & {$[0.066]$} & {$[0.050]$} & {$[0.035]$} & {$[0.052]$} & {$[0.036]$} & {$[0.052]$} & {$[0.056]$} \\
\hline \multirow[t]{2}{*}{ Age } & 0.001 & -0.001 & 0.000 & $0.007^{* *}$ & $0.006^{* *}$ & -0.002 & $-0.004^{* *}$ & 0.000 \\
\hline & {$[0.002]$} & {$[0.003]$} & {$[0.002]$} & {$[0.003]$} & {$[0.003]$} & {$[0.002]$} & {$[0.002]$} & {$[0.002]$} \\
\hline \multirow[t]{2}{*}{ Female } & $0.097^{* *}$ & 0.011 & $0.175^{* *}$ & -0.047 & $-0.263^{* * *}$ & $0.185^{* * *}$ & $-0.277^{* * *}$ & $-0.130^{* * *}$ \\
\hline & {$[0.041]$} & {$[0.044]$} & {$[0.065]$} & {$[0.057]$} & {$[0.064]$} & {$[0.062]$} & {$[0.049]$} & {$[0.043]$} \\
\hline \multirow[t]{2}{*}{ Native } & 0.037 & 0.026 & 0.084 & $0.174^{* * *}$ & -0.035 & $-0.155^{*}$ & -0.023 & 0.062 \\
\hline & {$[0.068]$} & {$[0.058]$} & {$[0.112]$} & {$[0.060]$} & {$[0.081]$} & {$[0.090]$} & {$[0.070]$} & {$[0.061]$} \\
\hline \multirow[t]{2}{*}{ Medium skilled } & 0.015 & 0.042 & 0.071 & 0.088 & $0.122^{* *}$ & 0.039 & $0.122^{* *}$ & 0.067 \\
\hline & {$[0.045]$} & {$[0.060]$} & {$[0.060]$} & {$[0.056]$} & {$[0.050]$} & {$[0.065]$} & {$[0.047]$} & {$[0.058]$} \\
\hline \multirow[t]{2}{*}{ High skilled } & -0.027 & -0.104 & $-0.142^{*}$ & $0.204^{* *}$ & $0.493^{* * *}$ & 0.080 & $0.372^{* * *}$ & $0.244^{* * *}$ \\
\hline & {$[0.060]$} & {$[0.070]$} & {$[0.072]$} & {$[0.074]$} & {$[0.083]$} & {$[0.075]$} & {$[0.065]$} & {$[0.084]$} \\
\hline \multirow[t]{2}{*}{ Cognitive skills } & 0.015 & $0.097^{* * *}$ & $0.123^{* * *}$ & $0.079^{* * *}$ & & & & \\
\hline & {$[0.028]$} & {$[0.023]$} & {$[0.037]$} & {$[0.018]$} & & & & \\
\hline \multirow[t]{2}{*}{ Social skills } & -0.003 & $0.053^{*}$ & 0.042 & $0.046^{* *}$ & & & & \\
\hline & {$[0.019]$} & {$[0.028]$} & {$[0.032]$} & {$[0.019]$} & & & & \\
\hline \multirow[t]{2}{*}{ Measurement error proxy } & & & & 0.011 & $0.105^{* * *}$ & $0.078^{* * *}$ & $0.130^{* * *}$ & $0.133^{* * *}$ \\
\hline & & & & {$[0.019]$} & {$[0.023]$} & {$[0.027]$} & {$[0.022]$} & {$[0.019]$} \\
\hline \multirow[t]{2}{*}{ Constant } & $-0.229^{*}$ & -0.006 & $-0.357^{*}$ & $-0.532^{* *}$ & -0.133 & -0.155 & $0.379^{* *}$ & -0.024 \\
\hline & {$[0.129]$} & {$[0.173]$} & {$[0.182]$} & {$[0.229]$} & {$[0.114]$} & {$[0.134]$} & {$[0.156]$} & {$[0.121]$} \\
\hline Clustered standard errors & Yes & Yes & Yes & Yes & Yes & Yes & Yes & Yes \\
\hline Fixed effects & Yes & Yes & Yes & Yes & Yes & Yes & Yes & Yes \\
\hline Observations & 2,149 & 1,556 & 1,556 & 2,149 & 1,556 & 1,556 & 1,683 & 1,683 \\
\hline Adjusted R-squared & -0.001 & 0.013 & 0.024 & 0.027 & 0.061 & 0.016 & 0.054 & 0.029 \\
\hline
\end{tabular}

Note: the measurement error proxy is defined for the difference between the importance and effectiveness of tasks (label 'imp-eff'), the effectiveness of task performance (label 'effectiveness') and the importance of tasks

(label 'importance'). Appendix B and Table 16 display the details of the measurement. Cognitive (social) skills refer to the number of cognitive (social) statements the respondent agrees with. The dependent variable

'matching' measures the matching quality of all skills. Cognitive (social) tasks refer to the number of cognitive (social) tasks the worker performs. The definitions and measurement of the variables are displayed in Table 14 in Appendix A. The Appendix displays the measurement of the proxy as well. Robust or clustered standard errors are in parentheses. Fixed effects refer to those at the two-digit occupational level (ISCO codes). 
to (8) present our previous estimates, including the proxy. The proxy for the measurement error has an insignificant coefficient in the matching estimation and a significant coefficient in the skill and task estimations. Respondents who value the importance and effectiveness of job tasks in the example job more have higher skill levels and jobs with more demanding tasks. The proxy for the error of matching is defined by the difference between importance and effectiveness; the insignificant coefficient suggests that the bias in the two cancels out. None of the previous results is affected by the inclusion of the proxy. City workers have a significantly positive bias to their answers compared to countryside workers. This bias does not, however, seem to drive our results.

The proxies do however not include a proxy of the over or underestimation of the worker concerning his/her skills, job tasks and job match. Such self-estimation errors hamper our analyses when the error varies between the city and the countryside. Spatial selection may lead to an over-representation of overconfident workers in cities and with that in a bias in the results of spatial skill and task patterns. Nothing guarantees that this is not the case. As we control for important covariates, education, jobs etc, we do not expect our results to be fully driven by such a possible bias. The question is however how such a bias would reflect in the measure of matching quality. The measure provides insight in the match between your tasks and your skills. If you are very confident, you will probably value both your skills and your job tasks more. Hence, it is unclear what effect this will have on the estimate of the match quality. We conclude that the results on the sorting of workers and jobs into cities may be hampered by subjectivity but that is it unlikely that such a bias fully drives our results. We have no reason to expect the results on the matching quality to be affected by subjectivity.

\subsection{Consumption preferences}

Urban areas facilitate interactions not only between workers and employers, but also between the workers themselves. Many people like to live in urban areas for social interaction and the larger variety of consumption amenities, from schools to theatres (Glaeser and Gottlieb 2006; Glaeser et al. 2001). Urban consumption variety is deemed a luxury good (Lee 2010). Thus, richer people tend to value urban consumption variety more than poor people. The relation between skills and wages suggests that more skilled people value urban consumption variety more and are more likely to locate in an urban area.

Our estimates of the spatial distribution of skills could reflect the sorting of more skilled workers into cities for consumption preferences instead of for job opportunities. The Netherlands is an interesting case to test whether jobs follow people or people follow jobs. A substantial part of the Dutch labour force (more than 50 percent; see Statistics Netherlands) does not work in the same municipality as they live. Distances are short in the Netherlands and commuting to work is very common. On average, a Dutchman travels 17 kilometres to work. Because many people choose to commute to work in the Netherlands, we can test whether the location of residence or the location of work reflects the matching and sorting patterns we find. In the sample, 27 percent of the individuals do not work and live in a location with the same density; 57 percent of these workers live in the countryside and work in the city, while the other 43 percent live in the city and work in the countryside. 
Table 8 presents the results of an estimations including a city dummy for the worker's location of residence instead of the location of work. The location of residence does not explain variation within the match of all worker skills to job tasks. Worker skills do vary with the density of the location of residence (see columns (2) and (3)). Workers who live in the city have more cognitive and social skills than workers who live in the countryside. The importance of cognitive and social job tasks does not vary with the density of the location of residence (columns (4) and (5)). Lastly, column (6) explains the quality of the match for a sample of commuters. The coefficient for the city of residence is negative and significant. Workers who commute from a large city of residence to the countryside for work have a worse match than workers who commute the other way.

The complexity of jobs and match quality only increase with the density of the worker's work location and not with the density of the location of residence. This underlines our hypothesis that the density of workers and jobs in cities results in better matching between the two. Our findings suggest that more skilled workers sort into cities of residence for consumption preferences or other reasons, such as the partner's location of work, while their location of work depends on job opportunities. Unfortunately, the dataset does not include information about distances from the location of living to dense labour markets. The dataset does not allow to control for the proximity of other labour markets.

Table 8 City of residence

\begin{tabular}{|c|c|c|c|c|c|c|}
\hline & \multirow[t]{2}{*}{ Matching } & \multicolumn{2}{|c|}{ Skills } & \multicolumn{2}{|c|}{ Tasks } & \multirow{2}{*}{$\begin{array}{c}\text { Commuters } \\
\text { Matching }\end{array}$} \\
\hline & & Cognitive & Social & Cognitive & Social & \\
\hline & (1) & $(2)$ & (3) & (4) & (5) & (6) \\
\hline \multirow[t]{2}{*}{ City of residence } & 0.024 & $0.139^{* * *}$ & $0.185^{* * *}$ & -0.002 & 0.041 & $-0.130^{*}$ \\
\hline & {$[0.036]$} & {$[0.047]$} & {$[0.047]$} & {$[0.047]$} & {$[0.053]$} & {$[0.065]$} \\
\hline \multirow[t]{2}{*}{ Age } & $0.007^{* *}$ & $0.006^{* * *}$ & -0.002 & $-0.004^{* *}$ & 0.000 & 0.001 \\
\hline & {$[0.003]$} & {$[0.002]$} & {$[0.002]$} & {$[0.002]$} & {$[0.002]$} & {$[0.004]$} \\
\hline \multirow[t]{2}{*}{ Female } & -0.049 & $-0.245^{* * *}$ & $0.175^{* * *}$ & $-0.250^{* * *}$ & $-0.099^{* *}$ & -0.133 \\
\hline & {$[0.057]$} & {$[0.043]$} & {$[0.053]$} & {$[0.048]$} & {$[0.045]$} & {$[0.086]$} \\
\hline \multirow[t]{2}{*}{ Native } & $0.167^{* * *}$ & -0.006 & -0.133 & -0.020 & 0.061 & 0.104 \\
\hline & {$[0.059]$} & {$[0.076]$} & {$[0.089]$} & {$[0.069]$} & {$[0.059]$} & {$[0.126]$} \\
\hline \multirow[t]{2}{*}{ Medium skilled } & 0.093 & $0.174^{* * *}$ & -0.002 & $0.124^{* *}$ & 0.073 & -0.051 \\
\hline & {$[0.055]$} & {$[0.046]$} & {$[0.054]$} & {$[0.049]$} & {$[0.058]$} & {$[0.119]$} \\
\hline \multirow[t]{2}{*}{ High skilled } & $0.215^{* * *}$ & $0.524^{* * *}$ & 0.087 & $0.371^{* * *}$ & $0.239^{* * *}$ & 0.049 \\
\hline & {$[0.074]$} & {$[0.067]$} & {$[0.054]$} & {$[0.064]$} & {$[0.082]$} & {$[0.142]$} \\
\hline \multirow[t]{2}{*}{ Cognitive skills } & $0.081^{* * *}$ & & & & & \\
\hline & {$[0.018]$} & & & & & \\
\hline \multirow[t]{2}{*}{ Social skills } & $0.046^{* *}$ & & & & & \\
\hline & {$[0.019]$} & & & & & \\
\hline \multirow[t]{2}{*}{ Constant } & $-0.494^{* *}$ & $-0.215^{*}$ & -0.176 & $0.386^{* *}$ & -0.067 & 0.187 \\
\hline & {$[0.224]$} & {$[0.110]$} & [0.133] & {$[0.157]$} & {$[0.108]$} & {$[0.278]$} \\
\hline Clustered standard errors & Yes & Yes & Yes & Yes & Yes & Yes \\
\hline Fixed effects & Yes & Yes & Yes & Yes & Yes & Yes \\
\hline Observations & 2,149 & 2,149 & 2,149 & 1,724 & 1,724 & 615 \\
\hline Adjusted R-squared & 0.025 & 0.055 & 0.016 & 0.033 & 0.008 & 0.005 \\
\hline
\end{tabular}

Note: the dependent variable 'matching' measures the matching quality of all skills. Cognitive (social) tasks refer to the number of cognitive (social) tasks the worker performs. Commuters work in a city with a different density than the city they live in. The definitions and measurement of the variables are displayed in Table 14 in Appendix A. Clustered standard errors are in parentheses. Fixed effects refer to those at the two-digit occupational level (ISCO codes). 


\subsection{Regional differences in the Netherlands}

Both the theoretical and empirical models neglect a city's hinterland. Cities are assumed to be isolated in space. In the case of the Netherlands, the hinterland across regions differs substantially. In the Randstad provinces, the distance between large cities is much smaller than in other provinces. Several studies therefore refer to the Randstad provinces as one city (e.g., Lambooy (1998)). If the Randstad operates as a single labour market, workers and employers search for matches within the Randstad. This suggests that the importance of a city's density should be more important outside the Randstad than within it.

Table 9 shows separate estimations for workers located in and outside the Randstad. The matching of skills to job tasks is better in cities than in the countryside in both regions. If we control for self-selection into occupational groups, this spatial variation remains significant only outside the Randstad. Workers who work in cities have more cognitive skills than workers in the countryside in both regions. In the Randstad, city workers also have more social skills. The complexity of jobs does not vary across cities or the countryside in the Randstad, whereas it does outside the Randstad.

The results in Table 9 suggest that the more integrated labour market in the Randstad diminishes the spatial variation in match quality. As the Randstad is often seen as one labour market, we assume that the Randstad operates more efficiently in the matching of workers to jobs as a relatively large market is created. The variation in the scope of the labour market likely affects the optimal spatial unit of observation in the Netherlands. Analyses for an alternative spatial unit may bias the results. This so-called modifiable area unit problem (MAUP) seems to bias our results for the Randstad area (for a discussion on the MAUP, see Briant et al. (2008)).

\subsection{Human capital accumulation}

Many studies suggest that cities stimulate knowledge spillovers and learning (e.g., Jaffe et al. (1993), Rosenthal and Strange (2008), Glaeser and Ressenger (2010)). The quicker and deeper human capital accumulation of workers in cities may be the driving force behind the higher productivity rates in these cities. Glaeser and Maré (2001), for instance, show that workers start earning an urban wage premium three to five years after their move to the city.

Considering our estimates, the quicker and better human capital accumulation in cities could result in a quicker development of workers' skills with respect to their tasks in cities. If workers in cities learn more and faster than workers in the countryside, their skill development towards job tasks will be better and faster as well. The results for the spatial distribution of worker skills could reflect a learning mechanism if these additional skills reflect newly learned skills instead of initial skills a worker had before the job match.

Table 10 shows estimates that test this hypothesis. The density of the work location does not explain the development of the job match between 2010 and 2012. City workers also do not learn more cognitive and social tasks at work (columns (2) and (3)) than workers in the countryside. Moreover, workers in dense cities learned their cognitive skills more often at school than workers in the countryside.

\subsection{Industrial and service jobs}

Location advantages vary across several stages and tasks of the production process. For instance, a metalworker performing routine tasks in a factory and an innovator 
Table 9 Regional differences in the Netherlands

\begin{tabular}{|c|c|c|c|c|c|c|c|c|c|c|}
\hline \multirow[b]{3}{*}{ Region } & \multirow{2}{*}{\multicolumn{2}{|c|}{ Matching }} & \multicolumn{4}{|c|}{ Skills } & \multicolumn{4}{|c|}{ Tasks } \\
\hline & & & \multicolumn{2}{|c|}{ Cognitive } & \multicolumn{2}{|c|}{ Social } & \multicolumn{2}{|c|}{ Cognitive } & \multicolumn{2}{|c|}{ Social } \\
\hline & Randstad & Other region & Randstad & Other region & Randstad & Other region & Randstad & Other region & Randstad & Other region \\
\hline & (1) & (2) & (3) & (4) & (5) & (6) & (7) & (8) & (9) & (10) \\
\hline \multirow[t]{2}{*}{ City } & 0.104 & $0.142^{* *}$ & $0.157^{* *}$ & $0.121^{* *}$ & $0.174^{* * *}$ & 0.012 & 0.017 & $0.133^{* *}$ & 0.026 & 0.071 \\
\hline & {$[0.093]$} & {$[0.056]$} & {$[0.076]$} & {$[0.058]$} & {$[0.060]$} & {$[0.055]$} & [0.099] & {$[0.055]$} & {$[0.100]$} & {$[0.068]$} \\
\hline \multirow[t]{2}{*}{ Age } & $0.009^{* *}$ & 0.006 & 0.005 & $0.006^{* *}$ & -0.003 & -0.001 & -0.003 & $-0.005^{*}$ & 0.003 & -0.001 \\
\hline & {$[0.004]$} & {$[0.004]$} & {$[0.003]$} & {$[0.002]$} & {$[0.003]$} & {$[0.002]$} & {$[0.003]$} & {$[0.003]$} & {$[0.004]$} & {$[0.003]$} \\
\hline \multirow[t]{2}{*}{ Female } & -0.000 & -0.065 & $-0.310^{* * *}$ & $-0.210^{* * *}$ & 0.091 & $0.229^{* * *}$ & $-0.246^{* * *}$ & $-0.246^{* * *}$ & -0.111 & -0.098 \\
\hline & {$[0.073]$} & {$[0.073]$} & {$[0.061]$} & {$[0.046]$} & {$[0.077]$} & {$[0.056]$} & {$[0.068]$} & {$[0.074]$} & {$[0.086]$} & {$[0.072]$} \\
\hline \multirow[t]{2}{*}{ Native } & 0.117 & $0.197^{* * *}$ & -0.007 & -0.007 & -0.067 & $-0.200^{* *}$ & 0.021 & -0.090 & 0.071 & -0.004 \\
\hline & {$[0.080]$} & {$[0.071]$} & [0.093] & {$[0.077]$} & {$[0.131]$} & {$[0.092]$} & {$[0.089]$} & [0.109] & {$[0.065]$} & {$[0.107]$} \\
\hline \multirow[t]{2}{*}{ Medium skilled } & $0.281^{* *}$ & -0.015 & $0.143^{*}$ & $0.153^{* *}$ & -0.121 & 0.008 & $0.209^{* *}$ & 0.075 & -0.014 & 0.097 \\
\hline & {$[0.114]$} & {$[0.069]$} & {$[0.081]$} & {$[0.062]$} & {$[0.108]$} & {$[0.062]$} & {$[0.078]$} & {$[0.067]$} & {$[0.108]$} & {$[0.060]$} \\
\hline \multirow[t]{2}{*}{ High skilled } & $0.262^{*}$ & $0.185^{* * *}$ & $0.515^{* * *}$ & $0.497^{* * *}$ & -0.112 & $0.168^{* *}$ & $0.328^{* * *}$ & $0.399^{* * *}$ & 0.025 & $0.327^{* * *}$ \\
\hline & {$[0.138]$} & {$[0.066]$} & {$[0.082]$} & {$[0.104]$} & {$[0.101]$} & {$[0.069]$} & {$[0.106]$} & {$[0.090]$} & {$[0.146]$} & {$[0.089]$} \\
\hline \multirow[t]{2}{*}{ Cognitive skills } & 0.038 & $0.113^{* * *}$ & & & & & & & & \\
\hline & {$[0.031]$} & {$[0.031]$} & & & & & & & & \\
\hline \multirow[t]{2}{*}{ Social skills } & $0.104^{* * *}$ & 0.007 & & & & & & & & \\
\hline & {$[0.030]$} & {$[0.027]$} & & & & & & & & \\
\hline \multirow[t]{2}{*}{ Constant } & $-0.762^{* * *}$ & -0.444 & -0.065 & $-0.279^{*}$ & 0.125 & -0.259 & $0.312^{*}$ & 0.418 & 0.037 & -0.028 \\
\hline & {$[0.253]$} & [0.295] & {$[0.191]$} & {$[0.152]$} & {$[0.248]$} & {$[0.186]$} & {$[0.161]$} & {$[0.253]$} & {$[0.223]$} & {$[0.252]$} \\
\hline Clustered standard errors & Yes & Yes & Yes & Yes & Yes & Yes & Yes & Yes & Yes & Yes \\
\hline Fixed effects & Yes & Yes & Yes & Yes & Yes & Yes & Yes & Yes & Yes & Yes \\
\hline Observations & 822 & 1327 & 822 & 1327 & 822 & 1327 & 665 & 1,059 & 665 & 1,059 \\
\hline Adjusted R-squared & 0.036 & 0.032 & 0.066 & 0.045 & 0.003 & 0.014 & 0.018 & 0.047 & -0.004 & 0.015 \\
\hline
\end{tabular}

Note: the dependent variable 'matching' measures the matching quality of all skills. Cognitive (social) tasks refer to the number of cognitive (social) tasks the worker performs. The definitions and measurement of the variables are displayed in Table 14 in Appendix A. The Randstad sample contains all workers who work in the following provinces: Noord-Holland, Zuid-Holland, and Utrecht. Clustered standard errors are in parentheses. Fixed effects refer to those at the two-digit occupational level (ISCO codes). 
Table 10 Learning in cities

\begin{tabular}{lccc}
\hline & Matching & Tasks learned at work & \\
& $\mathbf{2 0 1 0 - 2 0 1 2}$ & Cognitive & Social \\
\hline City & $\mathbf{( 1 )}$ & $\mathbf{( 2 )}$ & $\mathbf{( 3 )}$ \\
\hline Age & -1.022 & $-0.038^{* *}$ & -0.011 \\
& {$[1.158]$} & {$[0.018]$} & {$[0.020]$} \\
Female & $-0.276^{* * *}$ & $0.006^{* * *}$ & $0.007^{* * *}$ \\
& {$[0.051]$} & {$[0.001]$} & {$[0.001]$} \\
Native & 1.228 & 0.018 & 0.007 \\
& {$[1.219]$} & {$[0.025]$} & {$[0.015]$} \\
Medium skilled & -0.686 & 0.023 & 0.018 \\
High skilled & {$[2.677]$} & {$[0.031]$} & {$[0.024]$} \\
Cognitive skills & $-7.475^{* * *}$ & $-0.058^{* *}$ & -0.034 \\
Social skills & {$[2.124]$} & {$[0.022]$} & {$[0.023]$} \\
& $-9.673^{* * *}$ & $-0.123^{* * *}$ & $-0.110^{* * *}$ \\
Constant & {$[1.795]$} & {$[0.017]$} & {$[0.024]$} \\
& -0.940 & $-0.024^{* *}$ & -0.009 \\
Clustered standard errors & {$[0.585]$} & {$[0.012]$} & {$[0.007]$} \\
Fixed effects & 0.575 & 0.013 & 0.003 \\
Observations & {$[0.929]$} & {$[0.008]$} & {$[0.006]$} \\
Adjusted R-squared & $-54.573^{* * *}$ & $0.454^{* * *}$ & $0.504^{* * *}$ \\
\hline Note: & {$[3.684]$} & {$[0.083]$} & {$[0.062]$} \\
Yes & Yes & Yes \\
Yes & Yes & 1,501 & 1,496 \\
& 1,567 & 0.077 & 0.088 \\
\hline
\end{tabular}

Note: the dependent variable 'matching' measures the matching quality of all skills. Tasks learned at work is a dummy variable indicating whether cognitive (social) tasks are learned at work or not. The definitions and measurement of the variables are displayed in Table 14 in Appendix A. Clustered standard errors are in parentheses. Fixed effects refer to those at the two-digit occupational level (ISCO codes).

working for the same industry but in the research and development department face different advantages of dense areas. Different locations are beneficial for different stages of product life cycle (Harrison et al. 1996), firm life cycle (Duranton and Puga 2001), and industry life cycle (Desmet and Rossi-Hansberg 2009). This results in an unequal distribution of these production stages over space. Our theoretical model, however, suggests that the amount of vacancies and job seekers is larger in cities for all workers and employers. If, for instance, manufacturing jobs are overrepresented in the countryside, this would result in scale benefits in the countryside for these jobs instead of in the city. More land-intense and less knowledge-intense product processes result in less agglomeration economies for product production than for idea production (Glaeser and Ponzetto 2010). Therefore, we distinguish between industrial and service occupations. Industrial occupations focus on producing products, while service occupations focus on either producing ideas or providing services. Indeed, 47 percent of the service occupations are performed in the city, while only 31 percent of industrial occupations are.

Table 11 presents separate estimations for both occupation types. The coefficient for city work location is positive and insignificant for industrial occupations and positive and very significant for service occupations. Both the weaker spatial distribution of industrial 
Table 11 Industrial and service occupations

\begin{tabular}{|c|c|c|c|c|c|c|c|c|c|c|}
\hline & \multirow{2}{*}{\multicolumn{2}{|c|}{ Matching }} & \multicolumn{4}{|c|}{ Skills } & \multicolumn{4}{|c|}{ Tasks } \\
\hline & & & \multicolumn{2}{|c|}{ Cognitive } & \multicolumn{2}{|c|}{ social } & \multicolumn{2}{|c|}{ Cognitive } & \multicolumn{2}{|c|}{ Social } \\
\hline & Industrial & Service & Industrial & Service & Industrial & Service & Industrial & Service & Industrial & Service \\
\hline & (1) & (2) & (3) & (4) & (5) & (6) & (7) & (8) & (9) & (10) \\
\hline \multirow[t]{2}{*}{ City } & 0.166 & $0.094^{* *}$ & -0.033 & $0.164^{* * *}$ & 0.009 & $0.122^{* * *}$ & 0.198 & 0.070 & 0.313 & 0.016 \\
\hline & {$[0.124]$} & {$[0.035]$} & [0.102] & [0.049] & {$[0.185]$} & {$[0.028]$} & {$[0.216]$} & {$[0.047]$} & {$[0.186]$} & {$[0.055]$} \\
\hline \multirow[t]{2}{*}{ Age } & 0.000 & $0.007^{* *}$ & $0.013^{* * *}$ & $0.005^{* *}$ & $-0.007^{*}$ & -0.001 & 0.001 & $-0.005^{* *}$ & 0.001 & -0.000 \\
\hline & {$[0.004]$} & {$[0.004]$} & {$[0.004]$} & {$[0.002]$} & {$[0.003]$} & {$[0.002]$} & {$[0.003]$} & {$[0.002]$} & {$[0.006]$} & {$[0.002]$} \\
\hline \multirow[t]{2}{*}{ Female } & $-0.401^{*}$ & -0.003 & -0.169 & $-0.249 * * *$ & $0.358^{*}$ & $0.158^{* *}$ & $-0.443^{* *}$ & $-0.232^{* * *}$ & -0.069 & $-0.109^{* *}$ \\
\hline & {$[0.218]$} & {$[0.054]$} & [0.173] & {$[0.041]$} & [0.173] & {$[0.058]$} & {$[0.175]$} & {$[0.051]$} & {$[0.200]$} & {$[0.044]$} \\
\hline \multirow[t]{2}{*}{ Native } & 0.106 & $0.197^{* * *}$ & -0.298 & 0.030 & -0.083 & $-0.182^{*}$ & 0.077 & -0.033 & 0.240 & 0.017 \\
\hline & {$[0.185]$} & {$[0.062]$} & {$[0.176]$} & [0.083] & {$[0.154]$} & {$[0.102]$} & {$[0.179]$} & {$[0.072]$} & {$[0.178]$} & {$[0.063]$} \\
\hline \multirow[t]{2}{*}{ Medium skilled } & 0.041 & 0.097 & $0.350^{* * *}$ & $0.117^{* *}$ & 0.011 & -0.029 & $0.249^{* *}$ & 0.089 & $0.264^{* * *}$ & 0.002 \\
\hline & {$[0.129]$} & {$[0.058]$} & {$[0.108]$} & {$[0.050]$} & {$[0.096]$} & {$[0.063]$} & {$[0.103]$} & {$[0.055]$} & {$[0.071]$} & {$[0.075]$} \\
\hline \multirow[t]{2}{*}{ High skilled } & 0.284 & $0.204^{* *}$ & $0.563^{* * *}$ & $0.484^{* * *}$ & -0.103 & 0.090 & $0.450^{* *}$ & $0.338^{* * *}$ & $0.520^{* * *}$ & 0.158 \\
\hline & {$[0.180]$} & {$[0.079]$} & {$[0.160]$} & {$[0.074]$} & [0.108] & {$[0.059]$} & {$[0.204]$} & {$[0.070]$} & {$[0.124]$} & {$[0.100]$} \\
\hline \multirow[t]{2}{*}{ Cognitive skills } & $0.132^{* * *}$ & $0.071^{* * *}$ & & & & & & & & \\
\hline & {$[0.031]$} & {$[0.019]$} & & & & & & & & \\
\hline \multirow[t]{2}{*}{ Social skills } & -0.003 & $0.055^{* *}$ & & & & & & & & \\
\hline & {$[0.048]$} & {$[0.020]$} & & & & & & & & \\
\hline \multirow[t]{2}{*}{ Constant } & 0.193 & $-0.660^{* *}$ & -0.433 & -0.149 & -0.127 & -0.113 & 0.046 & $0.438^{* *}$ & $-0.865^{* * *}$ & 0.158 \\
\hline & {$[0.389]$} & {$[0.255]$} & {$[0.379]$} & {$[0.094]$} & [0.390] & {$[0.131]$} & {$[0.338]$} & {$[0.181]$} & {$[0.263]$} & {$[0.114]$} \\
\hline Clustered standard errors & Yes & Yes & Yes & Yes & Yes & Yes & Yes & Yes & Yes & Yes \\
\hline Fixed effects & Yes & Yes & Yes & Yes & Yes & Yes & Yes & Yes & Yes & Yes \\
\hline Observations & 363 & 1,786 & 363 & 1,786 & 363 & 1,786 & 287 & 1,437 & 287 & 1,437 \\
\hline Adjusted R-squared & 0.031 & 0.028 & 0.049 & 0.058 & 0.016 & 0.010 & 0.033 & 0.035 & 0.039 & 0.005 \\
\hline
\end{tabular}

Note: the dependent variable 'matching' measures the matching quality of all skills. Cognitive (social) tasks refer to the number of cognitive (social) tasks the worker performs. The definitions and measurement of the variables are displayed in Table 14 in Appendix A. Industrial occupations have ISCO codes 13, 31, 61, 62, 69, and 70-92. Clustered standard errors are in parentheses. Fixed effects refer to those at the two-digit occupational level (ISCO codes). 
occupations and the smaller number of observations can explain the insignificant coefficient for industrial occupations. Columns (3) to (6) show the distribution of worker skills for both occupation types. Again, only the spatial distribution of the service sector is significant. We do not find a significant spatial distribution for the importance of cognitive and social tasks for either type of occupation.

\subsection{Low, middle and high-skilled workers}

The theoretical model assumes the different segments to be totally 'segmented'. Workers and jobs do not match outside their segment. We assume segments to consist of both and education level and a broad occupational group. Different segments, such as low versus high-skilled workers, likely face different labour market characteristics and agglomeration forces (Glaeser and Maré 2001; Rosenthal and Strange 2008; Glaeser and Ressenger 2010; Eeckhout et al. 2010). Table 12 shows separate estimations for three education classes as the dataset does not allow the possibility to analyse each education-occupation segment separately. Columns (1) to (3) present the estimates for the quality of the match. The matching quality increases with the density of the location for low-skilled and, to somewhat lesser extent, middle-skilled workers. For high-skilled workers, the density does not affect the quality of the match. This finding probably reflects the mobility of the segment. Likely, high-skilled workers are more willing to move for their job than middle and low-skilled workers and therefore consider a broader region for a job match. This results in less influence of the thickness of the local labour market for their match quality. The spatial distributions of skills and tasks show a different pattern (columns (4)-(15)). Especially high-skilled workers tend to have more cognitive skills when they work in cities, while both high and middle-skilled workers tend to have more social skills. Only for highskilled workers the jobs contain more cognitive tasks in cities than in the countryside. These results underline the hypotheses that especially high-skilled workers are mobile in the Netherlands.

\subsection{Explaining regional wage differences}

Our results show that the matching of worker skills to job tasks is of better quality in the cities than in the countryside. Here, we test whether this better match quality determines part of the urban wage premium in the Netherlands. Clearly, a full assessment of the role of matching in urban wage premia is beyond the scope of this chapter and not feasible with our dataset. This section presents a simple back-of-the-envelope estimation and suggests that more productive labour matches in the cities result in higher wages.

Table 13 presents the results of a simple wage model. Workers in Dutch cities earn, ceteris paribus, 13 percent of a standard deviation more than workers in the countryside (column (1)). Column 2 shows that a one standard deviation better job match increases wages by 23 percent of a standard deviation. When we include both variables, both coefficients decrease slightly (column (3)).

Column (4) includes a worker's cognitive and social attitudes as additional skill information. These hardly affect the wage returns of the match quality. The coefficient of the urban wage premium does decrease slightly. Cognitive skills are valued positively, while social skills have no wage returns. Borghans et al. (2008) argue that the supply and demand of skills determine their wage returns. These authors' results 
Table 12 High, middle and low-skilled workers

\begin{tabular}{|c|c|c|c|c|c|c|c|c|c|c|c|c|c|c|c|}
\hline \multirow[b]{3}{*}{ Skill level } & \multicolumn{3}{|c|}{ Matching } & \multicolumn{6}{|c|}{ Skills } & \multicolumn{6}{|c|}{ Tasks } \\
\hline & \multirow[b]{2}{*}{ High } & \multirow[b]{2}{*}{ Middle } & \multirow[b]{2}{*}{ Low } & \multicolumn{3}{|c|}{ Cognitive } & \multicolumn{3}{|c|}{ Social } & \multicolumn{3}{|c|}{ Cognitive } & \multicolumn{3}{|c|}{ Social } \\
\hline & & & & High & Middle & Low & High & Middle & Low & High & Middle & Low & High & Middle & Low \\
\hline & (1) & (2) & (3) & (4) & (5) & (6) & (7) & (8) & (9) & (10) & (11) & (12) & (13) & (14) & (15) \\
\hline \multirow[t]{2}{*}{ City } & 0.050 & $0.153^{* *}$ & $0.267^{* * *}$ & $0.276^{* * *}$ & 0.063 & 0.063 & $0.108^{*}$ & $0.161^{* *}$ & 0.079 & $0.109^{*}$ & 0.050 & 0.186 & -0.033 & 0.070 & 0.236 \\
\hline & {$[0.036]$} & {$[0.061]$} & {$[0.082]$} & {$[0.085]$} & {$[0.067]$} & [0.059] & {$[0.058]$} & {$[0.061]$} & {$[0.102]$} & {$[0.056]$} & [0.064] & [0.125] & {$[0.076]$} & {$[0.082]$} & [0.145] \\
\hline \multirow[t]{2}{*}{ Age } & -0.004 & $0.017^{* * *}$ & $0.010^{*}$ & $0.007^{* *}$ & 0.001 & $0.008^{* * *}$ & $-0.007^{* *}$ & -0.002 & 0.004 & -0.000 & $-0.011^{* * *}$ & -0.004 & 0.005 & -0.004 & -0.001 \\
\hline & {$[0.003]$} & {$[0.005]$} & {$[0.005]$} & {$[0.003]$} & {$[0.003]$} & {$[0.002]$} & [0.003] & {$[0.003]$} & {$[0.005]$} & [0.003] & [0.003] & {$[0.005]$} & {$[0.004]$} & {$[0.003]$} & {$[0.006]$} \\
\hline \multirow[t]{2}{*}{ Female } & -0.085 & 0.006 & -0.087 & $-0.332^{* * *}$ & -0.135 & $-0.174^{*}$ & 0.066 & $0.205^{* *}$ & $0.367^{* * *}$ & $-0.339^{* * *}$ & $-0.195^{*}$ & -0.184 & $-0.158^{* * *}$ & -0.143 & 0.005 \\
\hline & {$[0.058]$} & [0.095] & [0.139] & {$[0.058]$} & [0.091] & [0.088] & [0.133] & {$[0.081]$} & {$[0.106]$} & {$[0.056]$} & [0.104] & [0.132] & [0.049] & [0.098] & [0.134] \\
\hline \multirow[t]{2}{*}{ Native } & -0.038 & 0.121 & 0.233 & 0.036 & -0.095 & 0.023 & -0.121 & $-0.228^{*}$ & -0.032 & $0.248^{* *}$ & -0.102 & -0.229 & 0.053 & 0.093 & -0.120 \\
\hline & {$[0.092]$} & [0.092] & {$[0.152]$} & {$[0.175]$} & [0.107] & {$[0.142]$} & [0.134] & {$[0.133]$} & [0.132] & {$[0.111]$} & [0.094] & {$[0.236]$} & [0.088] & {$[0.091]$} & [0.247] \\
\hline \multirow[t]{2}{*}{ Constant } & $0.520^{* *}$ & $-0.976^{* * *}$ & $-0.864^{* *}$ & $0.325^{*}$ & 0.087 & $-0.481^{*}$ & 0.360 & -0.143 & $-0.818^{* *}$ & $0.507^{* *}$ & $0.780^{* * *}$ & 0.167 & 0.261 & 0.202 & -0.256 \\
\hline & {$[0.220]$} & {$[0.287]$} & {$[0.347]$} & {$[0.184]$} & {$[0.230]$} & {$[0.276]$} & [0.243] & {$[0.224]$} & [0.322] & {$[0.228]$} & {$[0.222]$} & [0.479] & {$[0.208]$} & {$[0.251]$} & [0.419] \\
\hline Clustered standard errors & Yes & Yes & Yes & Yes & Yes & Yes & Yes & Yes & Yes & Yes & Yes & Yes & Yes & Yes & Yes \\
\hline Fixed effects & Yes & Yes & Yes & Yes & Yes & Yes & Yes & Yes & Yes & Yes & Yes & Yes & Yes & Yes & Yes \\
\hline Observations & 921 & 903 & 489 & 826 & 823 & 446 & 826 & 823 & 446 & 693 & 653 & 335 & 693 & 653 & 335 \\
\hline Adjusted R-squared & 0.002 & 0.032 & 0.020 & 0.041 & 0.002 & 0.016 & 0.007 & 0.016 & 0.016 & 0.030 & 0.015 & 0.015 & 0.006 & 0.002 & 0.002 \\
\hline
\end{tabular}

Note: the definitions and measurement of the variables are displayed in Table 14 in Appendix A. Clustered standard errors are in parentheses. Fixed effects refer to those at the two-digit occupational level (ISCO codes). 


\section{Table 13 Wage returns}

\begin{tabular}{|c|c|c|c|c|c|c|c|c|c|c|}
\hline & \multicolumn{10}{|c|}{ Gross monthly earnings } \\
\hline & (1) & (2) & (3) & (4) & (5) & (6) & (7) & (8) & (9) & (10) \\
\hline City & $\begin{array}{c}0.134^{* * *} \\
{[0.041]}\end{array}$ & & $\begin{array}{c}0.120^{* * *} \\
{[0.040]}\end{array}$ & $\begin{array}{c}0.129^{* * *} \\
{[0.042]}\end{array}$ & $\begin{array}{l}0.080^{* *} \\
{[0.039]}\end{array}$ & $\begin{array}{l}0.090^{* *} \\
{[0.040]}\end{array}$ & $\begin{array}{c}0.092^{* * *} \\
{[0.032]}\end{array}$ & $\begin{array}{c}0.099^{* * *} \\
{[0.030]}\end{array}$ & $\begin{array}{c}0.055 \\
{[0.034]}\end{array}$ & $\begin{array}{l}0.064^{*} \\
{[0.036]}\end{array}$ \\
\hline Matching & & $\begin{array}{c}0.226^{* * *} \\
{[0.030]}\end{array}$ & $\begin{array}{c}0.224^{* * *} \\
{[0.030]}\end{array}$ & $\begin{array}{c}0.221^{* * *} \\
{[0.033]}\end{array}$ & $\begin{array}{c}0.098^{* * *} \\
{[0.027]}\end{array}$ & $\begin{array}{c}0.088^{* * *} \\
{[0.028]}\end{array}$ & $\begin{array}{c}0.188^{* * *} \\
{[0.031]}\end{array}$ & $\begin{array}{c}0.195^{* * *} \\
{[0.036]}\end{array}$ & $\begin{array}{l}0.082^{* *} \\
{[0.030]}\end{array}$ & $\begin{array}{l}0.079^{* *} \\
{[0.032]}\end{array}$ \\
\hline Age & $\begin{array}{c}0.111^{* * *} \\
{[0.015]}\end{array}$ & $\begin{array}{c}0.096^{* * *} \\
{[0.014]}\end{array}$ & $\begin{array}{c}0.095^{* * *} \\
{[0.014]}\end{array}$ & $\begin{array}{c}0.094^{* * *} \\
{[0.014]}\end{array}$ & $\begin{array}{c}0.070^{* * *} \\
{[0.014]}\end{array}$ & $\begin{array}{c}0.071^{* * *} \\
{[0.015]}\end{array}$ & $\begin{array}{c}0.073^{* * *} \\
{[0.013]}\end{array}$ & $\begin{array}{c}0.072^{* * *} \\
{[0.014]}\end{array}$ & $\begin{array}{c}0.061^{* * *} \\
{[0.016]}\end{array}$ & $\begin{array}{c}0.061^{* * *} \\
{[0.016]}\end{array}$ \\
\hline Age square & $\begin{array}{c}-0.001^{* * *} \\
{[0.000]}\end{array}$ & $\begin{array}{c}-0.001^{* * *} \\
{[0.000]}\end{array}$ & $\begin{array}{c}-0.001^{* * *} \\
{[0.000]}\end{array}$ & $\begin{array}{c}-0.001^{* * *} \\
{[0.000]}\end{array}$ & $\begin{array}{c}-0.001 * * * \\
{[0.000]}\end{array}$ & $\begin{array}{c}-0.001 * * * \\
{[0.000]}\end{array}$ & $\begin{array}{c}-0.001^{* * *} \\
{[0.000]}\end{array}$ & $\begin{array}{c}-0.001^{* * *} \\
{[0.000]}\end{array}$ & $\begin{array}{c}-0.001^{* * *} \\
{[0.000]}\end{array}$ & $\begin{array}{c}-0.001^{* * *} \\
{[0.000]}\end{array}$ \\
\hline Female & $\begin{array}{c}-0.845^{* * *} \\
{[0.041]}\end{array}$ & $\begin{array}{c}-0.836^{* * *} \\
{[0.040]}\end{array}$ & $\begin{array}{c}-0.835^{* * *} \\
{[0.040]}\end{array}$ & $\begin{array}{c}-0.829^{* * *} \\
{[0.043]}\end{array}$ & $\begin{array}{c}-0.720^{* * *} \\
{[0.040]}\end{array}$ & $\begin{array}{c}-0.714^{* * *} \\
{[0.042]}\end{array}$ & $\begin{array}{c}-0.736^{* * *} \\
{[0.067]}\end{array}$ & $\begin{array}{c}-0.730^{* * *} \\
{[0.078]}\end{array}$ & $\begin{array}{c}-0.651^{* * *} \\
{[0.058]}\end{array}$ & $\begin{array}{c}-0.637^{* * *} \\
{[0.066]}\end{array}$ \\
\hline Native & $\begin{array}{c}0.075 \\
{[0.073]}\end{array}$ & $\begin{array}{l}-0.017 \\
{[0.067]}\end{array}$ & $\begin{array}{c}0.002 \\
{[0.068]}\end{array}$ & $\begin{array}{c}0.000 \\
{[0.071]}\end{array}$ & $\begin{array}{c}0.033 \\
{[0.062]}\end{array}$ & $\begin{array}{c}0.014 \\
{[0.065]}\end{array}$ & $\begin{array}{l}-0.029 \\
{[0.084]}\end{array}$ & $\begin{array}{l}-0.024 \\
{[0.080]}\end{array}$ & $\begin{array}{l}-0.002 \\
{[0.068]}\end{array}$ & $\begin{array}{l}-0.021 \\
{[0.072]}\end{array}$ \\
\hline Medium skilled & $\begin{array}{c}0.208^{* * *} \\
{[0.059]}\end{array}$ & $\begin{array}{c}0.187^{* * *} \\
{[0.058]}\end{array}$ & $\begin{array}{c}0.177^{* * *} \\
{[0.058]}\end{array}$ & $\begin{array}{l}0.138^{* *} \\
{[0.059]}\end{array}$ & $\begin{array}{l}0.103^{*} \\
{[0.057]}\end{array}$ & $\begin{array}{l}0.096^{*} \\
{[0.057]}\end{array}$ & $\begin{array}{c}0.059 \\
{[0.059]}\end{array}$ & $\begin{array}{c}0.030 \\
{[0.065]}\end{array}$ & $\begin{array}{l}-0.002 \\
{[0.059]}\end{array}$ & $\begin{array}{l}-0.002 \\
{[0.066]}\end{array}$ \\
\hline High skilled & $\begin{array}{c}0.843^{* * *} \\
{[0.055]}\end{array}$ & $\begin{array}{c}0.786^{* * *} \\
{[0.055]}\end{array}$ & $\begin{array}{c}0.761^{* * *} \\
{[0.055]}\end{array}$ & $\begin{array}{c}0.724^{* * *} \\
{[0.057]}\end{array}$ & $\begin{array}{c}0.578^{* * *} \\
{[0.059]}\end{array}$ & $\begin{array}{c}0.586^{* * *} \\
{[0.059]}\end{array}$ & $\begin{array}{c}0.531^{* * *} \\
{[0.064]}\end{array}$ & $\begin{array}{c}0.500^{* * *} \\
{[0.064]}\end{array}$ & $\begin{array}{c}0.396^{* * *} \\
{[0.060]}\end{array}$ & $\begin{array}{c}0.397^{* * *} \\
{[0.065]}\end{array}$ \\
\hline Cognitive skills & & & & $\begin{array}{l}0.045^{* *} \\
{[0.022]}\end{array}$ & & $\begin{array}{c}0.002 \\
{[0.022]}\end{array}$ & & $\begin{array}{l}0.027^{*} \\
{[0.015]}\end{array}$ & & $\begin{array}{l}-0.004 \\
{[0.018]}\end{array}$ \\
\hline Social skills & & & & $\begin{array}{l}-0.017 \\
{[0.023]}\end{array}$ & & $\begin{array}{l}-0.024 \\
{[0.022]}\end{array}$ & & $\begin{array}{l}-0.024 \\
{[0.024]}\end{array}$ & & $\begin{array}{l}-0.034 \\
{[0.022]}\end{array}$ \\
\hline Cognitive tasks & & & & & $\begin{array}{c}0.144^{* * *} \\
{[0.024]}\end{array}$ & $\begin{array}{c}0.150^{* * *} \\
{[0.025]}\end{array}$ & & & $\begin{array}{c}0.099^{* * *} \\
{[0.027]}\end{array}$ & $\begin{array}{c}0.103^{* * *} \\
{[0.024]}\end{array}$ \\
\hline Social tasks & & & & & $\begin{array}{c}0.068^{* * *} \\
{[0.022]}\end{array}$ & $\begin{array}{c}0.065^{* * *} \\
{[0.023]}\end{array}$ & & & $\begin{array}{l}0.068^{* *} \\
{[0.031]}\end{array}$ & $\begin{array}{l}0.070^{*} \\
{[0.034]}\end{array}$ \\
\hline Constant & $\begin{array}{c}-2.052^{* * *} \\
{[0.362]}\end{array}$ & $\begin{array}{c}-1.575^{* * *} \\
{[0.321]}\end{array}$ & $\begin{array}{c}-1.621^{* * *} \\
{[0.325]}\end{array}$ & $\begin{array}{c}-1.586^{* * *} \\
{[0.341]}\end{array}$ & $\begin{array}{c}-1.101^{* * *} \\
{[0.331]}\end{array}$ & $\begin{array}{c}-1.115^{* * *} \\
{[0.344]}\end{array}$ & $\begin{array}{c}-1.029 * * * \\
{[0.320]}\end{array}$ & $\begin{array}{c}-0.996^{* * *} \\
{[0.361]}\end{array}$ & $\begin{array}{c}-0.773^{* *} \\
{[0.372]}\end{array}$ & $\begin{array}{l}-0.765^{*} \\
{[0.400]}\end{array}$ \\
\hline Clustered standard errors & & & & & & & Yes & Yes & Yes & Yes \\
\hline Fixed effects & & & & & & & Yes & Yes & Yes & Yes \\
\hline Observations & 1,490 & 1,490 & 1,490 & 1,354 & 1,157 & 1,071 & 1,490 & 1,354 & 1,157 & 1,071 \\
\hline Adjusted R-squared & 0.393 & 0.427 & 0.430 & 0.435 & 0.443 & 0.450 & 0.308 & 0.307 & 0.325 & 0.325 \\
\hline
\end{tabular}

Note: the definitions and measurement of the variables are displayed in Table 14 in Appendix A. We indicate gross monthly wages as missing when a person earns nothing, less than nothing, or more than 10,000 euros a month. Robust or clustered standard errors are in parentheses. Fixed effects refer to those at the two-digit occupational level (ISCO codes). 
resemble ours and suggest that social skills are overrepresented relative to cognitive skills.

Additionally, we follow the task approach literature and proxy for worker skills with job tasks (for a review of this literature, see Acemoglu and Autor (2011)). This approach assumes that job tasks reflect work activities that produce output. The ongoing selfselection of workers into job tasks implies an interplay between workers skills and job tasks (Autor and Handel forthcoming). Columns (5) to (10) include information about a worker's job tasks and the job's broad occupational group. The performance of both cognitive and social job tasks is valued positively. A substantial part of the urban wage premium is explained by different job tasks: wage returns decrease by 12 to 8 percent of a standard deviation. In addition, the coefficient of match quality decreases substantially, from 0.22 to 0.10 . Column (6) includes both skills and tasks and shows that the latter are especially valued.

Lastly, columns (7) to (10) show fixed effects regressions explaining variation within broad occupational groups. The urban wage premia and the returns to match quality decrease when we include occupational fixed effects. Hence, the spatial distribution of occupations explains a substantial part of the spatial wage differences in the Netherlands. Columns (9) and (10) show substantial explanatory power of job tasks. As we control for additional cognitive and social job tasks, the spatial wage variation in the Netherlands becomes insignificant. This finding suggests that the spatial wage variation reflects different activities and not increasing returns to scale. Only the economic activity of workers explains spatial wage differences. The wage return of match quality remains significant but decreases to 9 percent of a standard deviation.

\section{Conclusion}

This paper estimates the spatial variation in the match quality of worker skills to job tasks in the Netherlands. We argue that the assignment of heterogeneous workers to heterogeneous jobs is better in a larger market. Tighter matches attract relatively skilled workers and relatively complex jobs to these large markets to optimise returns to their skills and complexity. Within the debate about the sorting of skilled workers, our findings suggest that workers indeed sort into cities for better matching opportunities. This pattern is apparent in the spatial distribution of occupations as well. The better matching of worker skills to job tasks results in higher individual wages for workers with the same occupation but with a better match.

This paper contributes to the literature about agglomeration economies by measuring labour market pooling directly (for reviews of this literature, see Rosenthal and Strange (2004), Glaeser and Gottlieb (2009)). Earlier work of, among others, Helsley and Strange (1990), Kim (1990), and Wheeler (2001) frames the idea of labour market pooling and the impact of scale on match quality. Extending the work of Petrongolo and Pissarides (2006), we measure the quality of the match between skills and tasks.

Regional inequality is a hot policy topic and many policy makers aim to reduce regional inequalities. The finding that the match quality of skills to jobs is better in cities indicates labour market advantages of economic concentration. Our results therefore suggest that hindering regional concentration and sorting of workers and 
firms could interfere economic development. Improving the measurement of skills, job tasks, matching quality and labour markets would be a valuable extension of this research.

\section{Endnotes}

${ }^{1}$ A disadvantage of self-reported job tasks is that the data might suffer from subjectivity. This concern is discussed in Section 5.1.

${ }^{2}$ The models of, for instance, Helsley and Strange (1990) and Duranton and Puga (2004) relate city formation to matching advantages. Our focus lies on scale effects in the match quality between heterogeneous workers and heterogeneous jobs. The main advantage of the dataset is the detailed information about the heterogeneity of workers, jobs, and matches, but information about location is limited. Therefore, we choose to set up a framework that focuses on scale effects for the match and does not explain city formation. Following Gautier et al. (2010) and Petrongolo and Pissarides (2006), we consider location characteristics as given.

${ }^{3}$ Note that the economic structure does not differ between the city and the countryside. The spatial division is not based on urban versus rural industries.

${ }^{4}$ If workers do consider future job opportunities or, for example, job opportunities after shocks, this would strengthen the advantage of the city as a location (e.g., Helsley and Strange (1990) and Strange et al. (2006)).

${ }^{5}$ The model ignores location choices based on social or living preferences. We admit that amenities can play a significant role in location choice and address this factor in the robustness section.

${ }^{6}$ This is a strong assumption to keep things simple. In reality, workers may find jobs outside their education segment.

${ }^{7}$ The standard model of Pissarides (2000) assumes a Cobb-Douglas function. Our matching function results from the assumption that both the value of being unemployed and the value of having a vacancy are zero. This assumption relates to our empirical analysis which contains a cross-section of matches which are already made. It therefore ignores unemployed workers and vacancies.

${ }^{8}$ By definition, the expected value of $\delta$ is 0 .

${ }^{9}$ Note that the difference between locations reflects differences in the density of agents.

${ }^{10}$ Another possible measure of skill variation could be the indicated effectiveness of workers in performing job tasks. This measure relates more to job tasks than to the degree of investment in developing skills. However, the survey asks about effectiveness directly after questions about the importance of job tasks. We are concerned about measurement error, since we assume workers will be reluctant to indicate they are ineffective in the performance of an important job task. This fear is underlined by weak correlations with other variables. Therefore, we exclude the information about effectiveness from our analyses.

${ }^{11}$ Self-reporting job tasks may induce measurement errors, as discussed in Section 3.4.

${ }^{12}$ For 9 percent of the sample, the difference between the two answers is more than one standard deviation.

${ }^{13}$ We obtain more observations for the matching quality of all skills than for the ones of cognitive and social skills. The results for the matching quality of all skills are similar in both samples of observations.

\section{Appendix}

\section{A Data description}

Chapter 4 employs the Longitudinal Internet Studies for the Social Sciences (LISS) panel of 3,000 Dutch individuals. This panel is the core element of a project titled 
'Measurement and Experimentation in the Social Sciences' from the Dutch research institute CentERdata. The chapter combines information from the background study, the work and schooling study, the personality study and an additional questionnaire about job tasks (carried out in May 2012). We drop all skilled agricultural, fishery, and forestry workers, since the locations of these occupations depend on natural resources.

The website of the LISS panel (http://www.lissdata.nl/) provides detailed information about the panel and questionnaires and provides access to the data.

Table 14 presents an overview of the included variables and Table 15 shows the correlation matrix of these variables.

\section{Table 14 List of variables}

\begin{tabular}{|c|c|c|c|c|}
\hline \multicolumn{3}{|c|}{ Dependent variables } & \multirow{2}{*}{$\begin{array}{l}\text { Mean } \\
0.00\end{array}$} & \multirow{2}{*}{$\frac{S D}{1.00}$} \\
\hline Matching all skills & $\begin{array}{l}\text { How do your knowledge and skills suit your } \\
\text { work? }\end{array}$ & Standardised & & \\
\hline \multirow[t]{2}{*}{ Matching cognitive skills } & $\begin{array}{l}\text { Inverse of the difference between standard- } \\
\text { ised cognitive job tasks }\end{array}$ & Standardised & 0.00 & 1.00 \\
\hline & and standardised cognitive skills. & & & \\
\hline \multirow[t]{2}{*}{ Matching social skills } & $\begin{array}{l}\text { Inverse of the difference between standard- } \\
\text { ised social job tasks. }\end{array}$ & Standardised & 0.00 & 1.00 \\
\hline & $\begin{array}{l}\text { and standardised social skills. See Table } 2 \text { for } \\
\text { the social skills. }\end{array}$ & & & \\
\hline \multirow[t]{2}{*}{ Cognitive skills } & $\begin{array}{l}\text { Number of cognitive statements with which } \\
\text { the worker agrees or strongly }\end{array}$ & Standardised & 0.00 & 1.00 \\
\hline & agrees. & & & \\
\hline \multirow[t]{2}{*}{ Social skills } & $\begin{array}{l}\text { Number of cognitive statements with which } \\
\text { the worker agrees or strongly }\end{array}$ & Standardised & 0.00 & 1.00 \\
\hline & $\begin{array}{l}\text { agrees, See Table } 2 \text { for cognitive and social } \\
\text { statements. }\end{array}$ & & & \\
\hline Cognitive tasks & $\begin{array}{l}\text { Number of core cognitive tasks the worker } \\
\text { performs. }\end{array}$ & Standardised & 0.00 & 1.00 \\
\hline \multirow[t]{2}{*}{ Social tasks } & $\begin{array}{l}\text { Number of core social tasks the workers per- } \\
\text { forms, }\end{array}$ & Standardised & 0.00 & 1.00 \\
\hline & See table 2 for cognitive and social job tasks. & & & \\
\hline \multirow[t]{2}{*}{ Gross monthly wage } & Personal gross monthly income in euros. & Standardised & 0.00 & 1.00 \\
\hline & Explanatory variables & & & \\
\hline \multirow[t]{2}{*}{ City } & $\begin{array}{l}\text { Dummy variable indicating whether the } \\
\text { worker works in a city with at least } 1,500\end{array}$ & Dummy & 0.45 & 0.50 \\
\hline & dwellings per square kilometre. & & & \\
\hline Age & Age & In years & 44.69 & 12.17 \\
\hline Female & $\begin{array}{l}\text { Dummy variable indicating whether the } \\
\text { worker is male or female. }\end{array}$ & Dummy & 1.53 & 0.50 \\
\hline Native & $\begin{array}{l}\text { Dummy variable indicating whether the } \\
\text { worker is native Dutch or not. }\end{array}$ & Dummy & 0.91 & 0.29 \\
\hline Skill dummies & $\begin{array}{l}\text { Indicates the worker's highest diploma } \\
\text { obtained. }\end{array}$ & & & \\
\hline Low skilled & Worker did not obtain a diploma. & Dummy & 0.20 & 0.40 \\
\hline Medium skilled & $\begin{array}{l}\text { Intermediate vocational education diploma. } \\
\text { or high school diploma at the pre-university } \\
\text { level. }\end{array}$ & Dummy & 0.37 & 0.48 \\
\hline High skilled & $\begin{array}{l}\text { Higher vocational education or university } \\
\text { diploma. }\end{array}$ & Dummy & 0.38 & 0.49 \\
\hline Occupation & One-digit ISCO occupations & Categorised 1-10 & & \\
\hline
\end{tabular}

Note: all standardised variables have a mean of zero and a standard deviation of one. We indicate gross monthly wages as missing if a person earns nothing, less than nothing, or more than 10,000 euros a month. 


\section{Table 15 Correlation matrix}

\begin{tabular}{|c|c|c|c|c|c|c|c|c|c|c|c|c|c|c|c|}
\hline & $(1)$ & (2) & (3) & (4) & (5) & (6) & (7) & (8) & (9) & $(10)$ & $(11)$ & $(12)$ & (13) & (14) & (15) \\
\hline (1) Age & 1.00 & & & & & & & & & & & & & & \\
\hline (2) Female & $\begin{array}{l}-0.10 \\
(0.00)\end{array}$ & 1.00 & & & & & & & & & & & & & \\
\hline (3) Native & $\begin{array}{c}0.02 \\
(0.23)\end{array}$ & $\begin{array}{c}0.02 \\
(0.37)\end{array}$ & 1.00 & & & & & & & & & & & & \\
\hline (4) Low skilled & $\begin{array}{c}0.15 \\
(0.00)\end{array}$ & $\begin{array}{c}0.01 \\
(0.77)\end{array}$ & $\begin{array}{c}0.00 \\
(0.90)\end{array}$ & 1.00 & & & & & & & & & & & \\
\hline (5) Medium skilled & $\begin{array}{l}-0.13 \\
(0.00)\end{array}$ & $\begin{array}{c}0.04 \\
(0.04)\end{array}$ & $\begin{array}{l}-0.03 \\
(0.09)\end{array}$ & $\begin{array}{l}-0.38 \\
(0.00)\end{array}$ & 1.00 & & & & & & & & & & \\
\hline (6) High skilled & $\begin{array}{l}-0.01 \\
(0.47)\end{array}$ & $\begin{array}{l}-0.04 \\
(0.04)\end{array}$ & $\begin{array}{c}0.05 \\
(0.02)\end{array}$ & $\begin{array}{l}-0.39 \\
(0.00)\end{array}$ & $\begin{array}{l}-0.60 \\
(0.00)\end{array}$ & 1.00 & & & & & & & & & \\
\hline (7) City & $\begin{array}{c}0.02 \\
(0.35)\end{array}$ & $\begin{array}{l}-0.02 \\
(0.25)\end{array}$ & $\begin{array}{l}-0.06 \\
(0.00)\end{array}$ & $\begin{array}{l}-0.12 \\
(0.00)\end{array}$ & $\begin{array}{l}-0.05 \\
(0.01)\end{array}$ & $\begin{array}{c}0.14 \\
(0.00)\end{array}$ & 1.00 & & & & & & & & \\
\hline (8) Match quality & $\begin{array}{c}0.15 \\
(0.00)\end{array}$ & $\begin{array}{l}-0.05 \\
(0.02)\end{array}$ & $\begin{array}{c}0.06 \\
(0.00)\end{array}$ & $\begin{array}{l}-0.07 \\
(0.00)\end{array}$ & $\begin{array}{l}-0.10 \\
(0.00)\end{array}$ & $\begin{array}{c}0.15 \\
(0.00)\end{array}$ & $\begin{array}{c}0.09 \\
(0.00)\end{array}$ & 1.00 & & & & & & & \\
\hline (9) Match quality, cognitive & $\begin{array}{l}-0.01 \\
(0.68)\end{array}$ & $\begin{array}{l}-0.06 \\
(0.01)\end{array}$ & $\begin{array}{l}-0.03 \\
(0.26)\end{array}$ & $\begin{array}{l}-0.06 \\
(0.02)\end{array}$ & $\begin{array}{l}-0.07 \\
(0.01)\end{array}$ & $\begin{array}{c}0.11 \\
(0.00)\end{array}$ & $\begin{array}{c}0.06 \\
(0.01)\end{array}$ & $\begin{array}{c}0.03 \\
(0.32)\end{array}$ & 1.00 & & & & & & \\
\hline (10) Match quality, social & $\begin{array}{l}-0.01 \\
(0.82)\end{array}$ & $\begin{array}{l}-0.02 \\
(0.44)\end{array}$ & $\begin{array}{l}-0.05 \\
(0.05)\end{array}$ & $\begin{array}{c}0.03 \\
(0.28)\end{array}$ & $\begin{array}{l}-0.04 \\
(0.15)\end{array}$ & $\begin{array}{c}0.02 \\
(0.39)\end{array}$ & $\begin{array}{c}0.01 \\
(0.61)\end{array}$ & $\begin{array}{c}0.01 \\
(0.70)\end{array}$ & $\begin{array}{c}0.10 \\
(0.00)\end{array}$ & 1.00 & & & & & \\
\hline (11) Cognitive skills & $\begin{array}{c}0.08 \\
(0.00)\end{array}$ & $\begin{array}{l}-0.17 \\
(0.00)\end{array}$ & $\begin{array}{c}0.00 \\
(0.88)\end{array}$ & $\begin{array}{l}-0.16 \\
(0.00)\end{array}$ & $\begin{array}{l}-0.11 \\
(0.00)\end{array}$ & $\begin{array}{c}0.26 \\
(0.00)\end{array}$ & $\begin{array}{c}0.12 \\
(0.00)\end{array}$ & $\begin{array}{c}0.15 \\
(0.00)\end{array}$ & $\begin{array}{c}0.29 \\
(0.00)\end{array}$ & $\begin{array}{c}0.08 \\
(0.00)\end{array}$ & 1.00 & & & & \\
\hline (12) Social skills & $\begin{array}{l}-0.02 \\
(0.38)\end{array}$ & $\begin{array}{c}0.08 \\
(0.00)\end{array}$ & $\begin{array}{l}-0.05 \\
(0.03)\end{array}$ & $\begin{array}{c}-0.02 \\
(0.41)\end{array}$ & $\begin{array}{l}-0.05 \\
(0.03)\end{array}$ & $\begin{array}{c}0.07 \\
(0.00)\end{array}$ & $\begin{array}{c}0.07 \\
(0.00)\end{array}$ & $\begin{array}{c}0.09 \\
(0.00)\end{array}$ & $\begin{array}{c}0.06 \\
(0.01)\end{array}$ & $\begin{array}{c}0.32 \\
(0.00)\end{array}$ & $\begin{array}{c}0.28 \\
(0.00)\end{array}$ & 1.00 & & & \\
\hline (13) Cognitive tasks & $\begin{array}{l}-0.02 \\
(0.40)\end{array}$ & $\begin{array}{l}-0.16 \\
(0.00)\end{array}$ & $\begin{array}{c}0.01 \\
(0.82)\end{array}$ & $\begin{array}{l}-0.21 \\
(0.00)\end{array}$ & $\begin{array}{l}-0.07 \\
(0.00)\end{array}$ & $\begin{array}{c}0.24 \\
(0.00)\end{array}$ & $\begin{array}{c}0.10 \\
(0.00)\end{array}$ & $\begin{array}{c}0.22 \\
(0.00)\end{array}$ & $\begin{array}{c}0.26 \\
(0.00)\end{array}$ & $\begin{array}{c}0.07 \\
(0.01)\end{array}$ & $\begin{array}{c}0.30 \\
(0.00)\end{array}$ & $\begin{array}{c}0.15 \\
(0.00)\end{array}$ & 1.00 & & \\
\hline (14) Social tasks & $\begin{array}{c}0.01 \\
(0.60)\end{array}$ & $\begin{array}{c}0.01 \\
(0.83)\end{array}$ & $\begin{array}{c}0.04 \\
(0.10)\end{array}$ & $\begin{array}{l}-0.15 \\
(0.00)\end{array}$ & $\begin{array}{l}-0.08 \\
(0.00)\end{array}$ & $\begin{array}{c}0.21 \\
(0.00)\end{array}$ & $\begin{array}{c}0.09 \\
(0.00)\end{array}$ & $\begin{array}{c}0.22 \\
(0.00)\end{array}$ & $\begin{array}{c}0.13 \\
(0.00)\end{array}$ & $\begin{array}{c}0.10 \\
(0.00)\end{array}$ & $\begin{array}{c}0.23 \\
(0.00)\end{array}$ & $\begin{array}{c}0.20 \\
(0.00)\end{array}$ & $\begin{array}{c}0.52 \\
(0.00)\end{array}$ & 1.00 & \\
\hline (15) Gross monthly earnings & $\begin{array}{c}0.19 \\
(0.00)\end{array}$ & $\begin{array}{l}-0.45 \\
(0.00)\end{array}$ & $\begin{array}{c}0.01 \\
(0.68)\end{array}$ & $\begin{array}{c}-0.22 \\
(0.00)\end{array}$ & $\begin{array}{l}-0.20 \\
(0.00)\end{array}$ & $\begin{array}{c}0.36 \\
(0.00)\end{array}$ & $\begin{array}{c}0.13 \\
(0.00)\end{array}$ & $\begin{array}{c}0.32 \\
(0.00)\end{array}$ & $\begin{array}{c}0.08 \\
(0.01)\end{array}$ & $\begin{array}{l}-0.02 \\
(0.57)\end{array}$ & $\begin{array}{c}0.25 \\
(0.00)\end{array}$ & $\begin{array}{l}-0.01 \\
(0.79)\end{array}$ & $\begin{array}{c}0.36 \\
(0.00)\end{array}$ & $\begin{array}{c}0.26 \\
(0.00)\end{array}$ & 1.00 \\
\hline
\end{tabular}

Note: The $\mathrm{p}$-values are in parentheses. The definitions and measurement of the variables are displayed in Table 14 
Table 16 Task-occupation combinations for example jobs

\begin{tabular}{lll}
\hline Task & \multicolumn{2}{l}{ Example jobs } \\
\hline Dealing with people & Secretary & Car mechanic \\
Persuading/influencing others & Nurse & Teacher \\
Physical strength & Grocer & Policeman \\
Dexterity & Plumber & Salesperson \\
Solving problems & Ticket collector & Journalist \\
Simple mathematics & Cashier & Real estate agent \\
\hline
\end{tabular}

\section{B Proxy measurement error}

Respondents were asked to indicate the importance of a certain job task for an example job followed by the effectiveness at performing that task in that occupation. For each task, the respondent was questioned about the importance and effectiveness of two example jobs. In total, two tasks were questions. Table 16 shows the task-occupation combinations.

The proxy for the measurement error is a respondent's indicated importance for a taskoccupation combination relative to its average indicated importance.

\section{Competing interests}

The IZA Journal of European Labor Studies is committed to the IZA Guiding Principles of Research Integrity. The author declares that she has observed these principles.

\section{Acknowledgments}

I thank Steven Brakman, Harry Garretsen, Bas ter Weel, an anonymous referee and participants at the Globalisation \& Agglomeration workshop at the SER for useful feedback on an earlier version of this paper.

Responsible editor: Sara De la Rica

Received: 5 August 2013 Accepted: 26 November 2013

Published: 27 Jan 2014

References

Acemoglu D, Autor D (2011) Skills, tasks and technologies: Implications for employment and earnings. In: Handbook for Labour Economics Volume 4, Part B. Elsevier, Amsterdam, pp 1043-1171

Autor D, Handel M (forthcoming) Putting tasks to the test: Human capital, job tasks and wages. Journal of Labor Economics Bacolod M, Blum B, Strange W (2009) Skills in the city. Journal of Urban Economics 65(2): 136-153

Becker G, Murphy K (1992) The division of labor, coordination costs and knowledge. Quarterly Journal of Economics 107(4): 1137-1160

Borghans L, Ter Weel B, Weinberg B (2006) People people: Social capital and the labor-market outcomes of underrepresented groups. NBER Working Paper 11985

Borghans, L, Ter Weel B, Weinberg B (2008) Interpersonal styles and labor market outcomes. Journal of Human Resources 43(4): 815-858

Briant A, Combes P, Lafourcade M (2008) Dots to boxes: Do the size and shape of spatial units jeopardize economic geography estimations? CEPR Discussion Paper 6928

Burdett K, Coles M (1997) Marriage and class. Quarterly Journal of Economics 112: 141-168

Costa D, Kahn M (2001) Power couples. Quarterly Journal of Economics 116: 1287-1315

Desmet K, Rossi-Hansberg E (2009) Spatial growth and industrial age. Journal of Economic Theory 144(6): 2477-2502

di Giovanni J, Levchenko A, Ortega F (2012) A global view of cross-border migration. IZA Discussion Paper 6584

Duranton G, Puga D (2001) Nursery cities: Urban diversity, process innovation, and the life cycle of products. American Economic Review 91(5): 1454-1477

Duranton, G, Puga D (2004) Micro-foundations of urban agglomeration economies In: Handbook of Regional and Urban Economics, Volume 4. Elsevier, Amsterdam, pp 2063-2117

Eeckhout J, Pinheiro R, Schmidheiny K (2010) Spatial Sorting: Why New York, Los Angeles and Detroit attract the greatest minds as well as the unskilled. CEPR Discussion Paper 8151

Gautier P, Svarer M, Teulings C (2010) Marriage and the city: Search frictions and sorting of singles. Journal of Urban Economics 67: 206-218

Glaeser E, Gottlieb J (2006) Urban resurgence and the consumer city. Urban Studies 43(8): 1275-1299

Glaeser E, Kolko J, Saiz A (2001) Consumer city. Journal of Economic Geography 1: 27-50

Glaeser E, Maré D (2001) Cities and skills. Journal of Labor Economics 19(2): 316-342

Glaeser E, Ponzetto A (2010) Agglomeration economics. The University of Chicago Press, Chicago, IL United States. chapter Did the death of distance hurt Detroit and help New York? pp. 303-337

Glaeser E, Ressenger M (2010) The complementarity between cities and skills. Journal of Regional Science 50(1): 221-244 
Glaeser EL, Gottlieb JD (2009) The wealth of cities: Agglomeration economies and spatial equilibrium in the United States. Journal of Economic Literature 47(4): 983-1028

Harrison B, Kelley M, Gant J (1996) Specialization versus diversity in local economies: The implications for innovative private-sector behavior. Cityscape: A Journal of Political Development and Research 2(2): 61-93

Heckman J, Stixrud J, Urzua S (2006) The effects of cognitive and noncognitive abilities on labor market outcomes and social behavior. Journal of Labor Economics 24(3): 411-482

Helsley R, Strange W (1990) Matching and agglomeration economies in a system of cities. Regional Science and Urban Economics 20(2): 189-212

Jaffe A, Trajtenberg M, Henderson R (1993) Geographic localization of knowledge spillovers as evidence by patent citations. Quarterly Journal of Economics 108(3): 577-598

Kim S (1990) Labor heterogeneity, wage bargaining, and agglomeration economies. Journal of Urban Economics 28(2): 160-177

Kim, S (1991) Heterogeneity of labor market and city size in an open spatial economy. Regional Science and Urban Economics 21(1): 109-126

Lambooy B (1998) Polynucleation and economic development: The Randstad. European Planning Studies 4: 456-466

Lee S (2010) Ability sorting and consumer city. Journal of Urban Economics 68: 20-33

Marshall A (1920) Principles of economics. MacMillan, London

Petrongolo B, Pissarides C (2001) Looking into the black-box: A survey of the matching function. Journal of Economic Literature 39(2): 390-431

Petrongolo B, Pissarides C (2006) Scale effects in market search. Economic Journal 116: 21-44

Pissarides C (2000) Equilibrium unemployment theory. MIT Press, Cambridge Mass

Rosenthal S, Strange W (2004) Evidence on the nature and sources of agglomeration economies. In: Handbook of Urban and Regional Economics, Volume 4. Elsevier, Amsterdam, pp 2119-2172

Rosenthal, S, Strange W (2008) The attunuation of human capital spillovers. Journal of Urban Economics 64: 373-389

Strange W, Hejazi W, Tang J (2006) The uncertain city: Competitive instability, skills, innovation and the strategy of agglomeration. Journal of Urban Economics 59(3): 331-351

Teulings C (1995) The wage distribution in a model of the assignment of skills to jobs. Journal of Political Economy 103(2): 280-315

Venables A (2011) Productivity in cities: Self-selection and sorting. Journal of Economic Geography 11:241-252

Wheeler A (2001) Search, sorting and urban agglomeration. Journal of Labor Economics 19(4): 880-898

10.1186/2193-9012-3-2

Cite this article as: Kok: Matching worker skills to job tasks in the Netherlands: sorting into cities for better careers. IZA Journal of European Labor Studies 2014, 3:2

\section{Submit your manuscript to a SpringerOpen ${ }^{\odot}$ journal and benefit from:}

- Convenient online submission

- Rigorous peer review

- Immediate publication on acceptance

- Open access: articles freely available online

- High visibility within the field

- Retaining the copyright to your article

Submit your next manuscript at $\boldsymbol{\triangleright}$ springeropen.com 